\title{
RACE TREASON: THE UNTOLD STORY OF AMERICA'S BAN ON POLYGAMY
}

\section{MARTHA M. ERTMAN*}

Today's ban on polygamy grew out of nineteenth century Americans' view that Mormons committed two types of treason. First, antipolygamists charged Mormons with political treason by establishing a separatist theocracy in Utah. Second, they saw a social treason against the nation of White citizens when Mormons adopted a supposedly barbaric marital form, one that was natural for "Asiatic and African" people, but so unnatural for Whites as to produce a new, degenerate species that threatened the project of white supremacy. This Article reveals how both kinds of treason provided the foundation of polygamy law through the discourse of legal, political and medical "experts," as well as, most vividly, cartoons of the day. This discourse designated the overwhelmingly White Mormons as non-White to justify depriving them of citizenship rights such as voting, holding office, and sitting on juries. Paralleling the Mormon question to miscegenation disputes also raging in the decades after the Civil War, the Article suggests two theoretical perspectives to understand the "blackening" of Mormons. First, postcolonial theorist Edward Said's concept of Orientalism helps explain how designating Mormons a subject race rendered their subjection inevitable. Second, Sir Henry Maine's 1864 observation that progressive societies move from status to contract reveals the visceral defense of status embedded in antipolygamy discourse. That defense of status may also have implicated other ways status was giving way to contract, such as wage labor replacing slavery and the partnership theory of marriage beginning to displace coverture. In either case,

* Carole \& Hanan Sibel Research Professor, University of Maryland School of Law. For helpful comments on earlier incarnations of this paper, I extend my thanks to Taunya Banks, Beth Clement, Adrienne Davis, Nancy Ehrenreich, Katherine Franke, Robert Glennon, Karen Lash, Laura Kessler, Bob Pollak, Carol Rose, Jana Singer, Kathryn Stockton, David Super, Chris Talbot, and participants at faculty workshops at George Washington University, the University of Utah, the University of Maryland, Washington University in St. Louis, and Roger Williams University Law School, the American Constitution Society's law and religion conference at West Virginia University Law School, the annual meetings of the Association of Matrimonial Lawyers, and the Law \& Society Association. For invaluable research assistance, I thank Emily Gelman, Sujeet Rao, Gabriel Steele, and Joseph Stoval, as well as University of Utah Law School librarian Lee Warthen. For financial and institutional support I am indebted both to the University of Utah and the University of Maryland, where Susan Herrick and Susan McCarty in the Thurgood Marshall Law Library provided superlative research support. 
the Article contends, the racial foundations of American antipolygamy law require us to rethink our own often reflexive condemnation of the practice. It concludes by suggesting three questions to help us frame that inquiry, asking: (1) whether we need to rethink this rarely-enforced ban; (2) whether current antipolygamy law associates polygamy with barbarism, foreignness, and people of color; and (3) whether it is coincidental that the plain language of the Defense of Marriage Act prohibits both polygamy and same-sex marriage.

\section{INTRODUCTION}

[R]ace is at the center of all of American history. - Ken Burns ${ }^{1}$

Many people think that American law bans polygamy to ensure women's equality and shield teenage girls from marrying old men. ${ }^{2}$ But that notion is largely wrong, at least if we interpret the relevant cases and statutes in light of the intentions of the lawmakers who enacted four federal statutes and the courts that upheld them in a line of cases that are still cited as good law. They were hardly concerned with gender equality or protecting children's safety. Instead, the statutes went far beyond criminalizing polygamy, depriving Mormon men and women of voting and other citizenship rights to achieve the larger goal of preventing the traitorous establishment of a separatist theocracy in Utah. Polygamy was merely a symptom, fascinatingly salacious and easily ridiculed, of the pathology that most Americans saw in Mormonism. However, knowing the treason-based genesis of antipolygamy law need not force us to rethink the ban on polygamy. Treason remains unlawful, making it a permissible justification for the law today.

But race is also at the center of antipolygamy law, in a way that forces us to rethink the ban itself. Many Americans, from the highest levels of government to political cartoonists, viewed the Mormons' political treason as part of a larger, even more sinister offense that I call race treason.

\footnotetext{
${ }^{1}$ See Interview by Mark Hall with Ken Burns, Documentarian, PBS (Jan. 21, 1997), available at http://www.pbs.org/jefferson/making/KB_00.htm.

2 See, e.g., Frances Raday, Secular Constitutionalism Vindicated, 30 CARDOZO L. REv. 2769, 2780-81 (2009); Dennis Wagner, After Raid, Other Polygamists Fear They're Next, ARIz. RePUB., June 1, 2008, at 1. For a thorough response to these views, see Shayna M. Sigman, Everything Lawyers Know about Polygamy is Wrong, 16 CoRnelL J. L. \& PuB. POL’Y 101 (2006).
} 
According to this view, polygamy was natural for people of color, but unnatural for White ${ }^{3}$ Americans of Northern European descent. When Whites engaged in this unnatural practice, antipolygamists contended, they produced a "peculiar race." 4 Antipolygamists linked this physical degeneration to Mormons' submission to despotism, reasoning that their primitive form of government was common among supposedly backward races. The Supreme Court accepted this argument in the leading antipolygamy case, Reynolds v. United States, in which it rejected Mormon claims that polygamy was protected as the free exercise of religion. ${ }^{5}$ The Court reasoned that polygamy was "odious among the northern and western nations of Europe," "almost exclusively a feature of the life of Asiatic and of African people," and ultimately "fetters the people in stationary despotism." "Well into the twentieth century, many Americans continued to associate White Mormons with people of color, as evidenced by a character's quip in Jack London's 1914 novel, "They ain't whites; they're Mormons."7

This racialization requires us to ask whether the polygamy ban today continues to import those white supremacist values. In another context, states criminalized cocaine and marijuana in the early twentieth century to police and generally demonize Chinese and Mexican immigrants

\footnotetext{
3 This Article capitalizes "White” and "Black." Stylistically, "White” should be capitalized when it identifies a racial or ethnic group, since other group designations, such as African American and Chinese, are capitalized. Substantively, capitalization recognizes "White" as a category, contrary to the common tendency to leaving "white" lower-case while other racial designations are capitalized. This small change invites the reader to see how law treats Whiteness not as a neutral description of skin but as an aspiration or entitlement, a norm to which other categories are compared. Peggy PASCOE, What Comes NATURAlly: Miscegenation LAW AND the MAKing of RACE in AMERicA 14 (2009). Following Pascoe, this Article uses the lower case when discussing "white supremacy." Id. at 13 .

${ }^{4}$ Christine Talbot, Mormons, Polygamy and the American Body Politic: Contested Citizenship, 1852-1890, at 335 (2006) (unpublished Ph.D. dissertation, University of Michigan) (quoting Surgeon General’s OfFice Statistical RePORT 302 (1860)) (on file with author).

598 U.S. 145 (1879).

${ }^{6}$ Id. at 164, 165-66. The Supreme Court reaffirmed the link between polygamy and barbarism as recently as 1946. See Cleveland v. United States, 329 U.S. 14 (1946).

7 JACK LONDON, THE Star Rover (Arcadia House 1950) (1914), quoted in TERRYL L. GiVENS, THE ViPER ON THE HEARTH 135 (1997).
} 
as well as African Americans. ${ }^{8}$ By the late twentieth century, that policy, though officially rejected, found expression in federal sentencing guidelines that penalized offenses related to crack cocaine (more common in African American communities), more harshly than powder cocaine (more common in White communities). ${ }^{9}$ There, as here, virulent racial motivations that animated a legal rule requires us to examine the law`s current incarnation to ensure it has shed the taint of its origin.

Casting overwhelmingly White Mormons as non-White required rhetorical slights of hand. While Mormons' distinctive theology and social organization were politically unsettling in many ways, the practice of polygamy justified the larger culture's demotion of Mormons from full citizenship on the grounds of racial inferiority. This Article tells the story of race in polygamy law through the words of government actors and scholars, using political cartoons to literally illustrate the widespread view of Mormons as race traitors.

It then offers two theoretical frames through which to view nineteenth century perceptions of polygamy as race treason: Orientalism and jurisprudential insights about the tensions between status and contract. Edward Said's work on Orientalism offer some clues as to why cartoonists might have portrayed Mormon polygamists as Black and Asian. ${ }^{10}$ Viewing the discourse as Orientalist - essentially an "us/them" rubric that primarily underpins colonialism - shows that antipolygamy discourse also spoke of Mormon polygamy in "us/them" terms, treating polygamists not as people, but as problems to be solved. The most valuable insight Orientalism offers here is that framing a group as Oriental—an inherently backward, sensual, and therefore subordinated Other-makes its subjection inevitable. ${ }^{11}$ Thus

\footnotetext{
${ }^{8}$ Doris Marie Provine, Unequal Under Law: Race and the War on Drugs 62-75 (2007); Michael M. Cohen, Jim Crow's Drug War: Race, Coca-Cola and the Southern Origins of Drug Prohibition, 12 SOUTHERn Cultures 55, $56-57$ (2006); PAul Butler, LeT’s Get FreE: A Hip-Hop TheOry OF Justice 44-45 (2009)..

${ }^{9}$ Richard C. Boldt, Construction of Responsibility in the Criminal Law, 140 U. PA. L. Rev. 2245, 2321-22 (1992); Kenneth B. Nunn, Race, Crime and the Pool of Surplus Criminality: Or Why the "War on Drugs" was a "War on Blacks," 6 J. GENDER, RACE \& JusT. 381 (2002).

${ }^{10}$ EdWARD SAID, ORIENTALISM (1979).

${ }^{11}$ Id. at 3. For further discussion of Orientalist frameworks for understanding popular and legal views of Mormons in the nineteenth century, see Christine Talbot, "Turkey is in our Midst:" Orientalism and Contagion in Nineteenth Century Anti-Mormonism, 8 J.L. \& FAM. STUD. 363 (2006). For further discussion of Orientalism as applied to legal issues more generally, see Teemu Ruskola, Legal Orientalism, 101 MicH. L. REV. 179 (2002).
} 
the public imagination's construction of Mormons as members of subject racial groups (Asian and Black, mainly) played a crucial role in subjecting Mormons to federal control. ${ }^{12}$

An alternative, or perhaps complementary, interpretation turns on the famous 1864 assertion of English comparative jurist Sir Henry Maine that "the movement of the progressive societies has hitherto been a movement from Status to Contract." 13 This insight situates seismic nineteenth century changes - such as slavery incrementally giving way to wage labor and coverture eroding through reforms like the Married Women's Property Acts-as part of a larger, progressive transition away from family and toward individuals as the organizing principles of legal regulation. $^{14}$

Applying Henry Maine's insight to the polygamy debates reveals a complex tension between status and contract. Both sides raised issues of consent, a foundational component of contractualism. Antipolygamists contended that no sane White woman would consent to polygamy, and Mormons countered that the federal government should not coerce people into monogamy when their religious beliefs dictated that they practice polygamy. Similarly, both forms of marriage assigned men and women rights and responsibilities based on their status. Status-based rules excluded monogamous wives from aspects of public life such as the practice of law. ${ }^{15}$ Along the same lines, the "Patriarchal Principle," as the Mormons called polygamy, reaffirmed the status-based authority of fathers and husbands that the rest of America was slowly leaving behind. ${ }^{16}$ In short, status and contract played key roles in both monogamy and polygamy.

However, we can see monogamy as substantively more contractual, and procedurally more status-oriented. Polygamy, conversely, was substantively grounded in status, but procedurally more contractual. Procedure here has both micro and macro aspects. By micro, I mean to designate individuals' entry and exit from marriage. Macro, in contrast, refers to broader levels of regulation. Focusing on the micro or individual, Mormon polygamy was contractual in its liberal divorce rules. At the macro

\footnotetext{
12 See infra Part III.A.

${ }^{13}$ Henry Sumner Maine, AnCient Law 165 (3d Am. ed. 1888).

${ }^{14}$ Id. at 163.

${ }^{15}$ See, e.g., Bradwell v. Illinois, 83 U.S. 130, 141 (1873) (Bradley, J., concurring).

16 Sarah Barringer Gordon, The Mormon Question: Polygamy and CONSTITUTIONAL CONFLiCT IN NinETEENTH-CENTURY AMERICA 3 (2002).
} 
or general level, it offered a way to "contract out" of monogamy into an alternative marital regime. This contractualism, I argue, played a central role in antipolygamy law. Polygamy constituted, for the rest of the nation, the most obvious evidence of how wrongheaded Mormons were to "contract out" of the nineteenth century American polity by establishing a separatist culture and economy.

This Article uses political cartoons of the day to demonstrate how viscerally the American polity fought against the Mormons' attempt at private ordering, deploying images of domestic and governmental disorder to rail against the chaotic consequences of abandoning status in marriage. In the cartoons, race and gender served as shorthand for status, the notion of assigned, inherent and unchanging roles. Because marriage was deeply raced and gendered, and not coincidentally defined citizenship, ${ }^{17}$ antipolygamists' equation of polygamy with Asian and Black foreignness reaffirmed the centrality of Whiteness to full citizenship. Equating Whiteness with citizenship mattered enormously in the time of which we speak. Abolitionists and Freedmen pushed hard for full civic membership for the freed slaves. The cartoons here oppose it, using polygamy to beat back African Americans' claims to civil membership in the wake of the Civil War. ${ }^{18}$

This Article critically reads the historical record to uncover these themes. Part I sets the stage by elaborating the common nineteenth century view of Mormons as political traitors. ${ }^{19}$ Part II then documents the related charge of race treason reflected in antipolygamy rhetoric in politics, medicine, the academy, and political cartoons. Part III tries to make sense of these remarkable facts by situating them within the theoretical frameworks of Orientalism and the move from status to contract. Finally, having demonstrated the dubious provenance of American polygamy law,

${ }^{17}$ Citizenship can both be literal, as in being an American citizen, and cultural, as in being one holding rights and duties of citizenship such as voting, holding office, and entering contracts. This Article generally uses "citizenship” in this second sense, sometimes using the term "civic membership" to capture participation in the polity. For fuller discussions of ways that race and marriage influenced both kinds of citizenship, see NANCY F. Cott, Public Vows: A History of Marriage AND the NAtion 117 (2000), and Ariela Gross, What Blood Won’t Tell: A History of Race on Trial in AMERicA 6 (2008).

${ }^{18}$ Kelly Elizabeth Phipps, Note, Marriage and Redemption: Mormon Polygamy $n$ the Congressional Imagination, 1862-1887, 95 VA. L. REV. 435, 441, 474 (2009).

19 For a full articulation of the association between Mormon polygamy and treason, including other historical details from Reynolds v. United States, 98 U.S. 154 (1879), see Martha M. Ertman, The Story of Reynolds v. United States: Federal "Hell Hounds” Punishing Mormon Treason, in FAMILY LAW STORIEs 51 (Carol Sanger ed., 2007). 
the Article ends with Part IV posing three questions that could structure further inquiry. First, why rethink a ban that affects few people, due to both rarity of prosecution and its practice by isolated religious sects? Second, do we still associate plural marriage with barbarism, foreignness, and people of color? Third and finally, is it a coincidence that the plain language of the Defense of Marriage Act (DOMA) bans both polygamy and same-sex marriage? ${ }^{20}$

\section{MORMON POLYGAMY AS TREASON}

In Reynolds v. United States, the Supreme Court upheld the first of four statutes that Congress passed to force Mormons to abandon the practice of polygamy. ${ }^{21}$ First Amendment scholars have debated Reynolds' division between permissible limits on conduct and impermissible limits on belief. $^{22}$ But what was so bad about that conduct?

The Court justified criminalizing Mormon polygamy in two passages that link polygamy first to "Asiatic and African people," then to "stationary despotism."23 But it is hard to fathom why the Court cared who else, other than the Mormons, practiced polygamy, or why all three branches of government (and indeed virtually the entire nation) cared so much about a religious community in a remote part of the country. This Part mines the historical record to answer these questions, concluding that the federal government, and most Americans, were more concerned with the political and racial implications of Mormon polygamy than with the practice of polygamy per se. These concerns are best described as a view of Mormon polygamy as political and race treason.

${ }^{20}$ Defense of Marriage Act, Pub. L. No. 109-199, § 3, 110 Stat. 2419, 2419 (1996) (codified at 1 U.S.C. $\S 7$ (2009)) (“[T]he word 'marriage' means only a legal union between one man and one woman as husband and wife ....”).

${ }^{21} 98$ U.S. 145 (1879).

${ }^{22}$ See, e.g., Jesse H. Choper, The Religion Clauses of the First Amendment: Reconciling the Conflict, 41 U. PITT. L. REV. 673 (1980); Ray J. Davis, Plural Marriage and Religious Freedom: The Impact of Reynolds v. United States, 15 ARIz. L. REV. 287 (1973); Donald L. Drakeman, Reynolds v. United States: The Historical Construction of Constitutional Reality, 21 Const. Comment. 697 (2004); Christopher L. Eisgruber \& Lawrence W. Sager, The Vulnerability of Conscience: The Constitutional Basis for Protecting Religious Conduct, 61 U. CHI. L. REv. 1245 (1994); Marci A. Hamilton, The Belief/Conduct Paradigm in the Supreme Court's Free Exercise Jurisprudence: A Theological Account of the Failure to Protect Religious Conduct, 54 OHIO ST. L.J. 713 (1993).

\footnotetext{
${ }^{23}$ Reynolds, 98 U.S. at 164, 165-66.
} 
Treason means different things in different contexts. In ordinary speech, treason is as much a "violation of allegiance toward one's sovereign or country" as "waging war against" it. ${ }^{24}$ Constitutionally, however, treason is narrowly defined as encompassing only the acts of "[l]evying War against [the United States] or in adhering to their Enemies, [or] giving them Aid and Comfort.” ${ }^{25}$ This Part reveals the underpinning for claims that Mormons committed both kinds of treason.

Like the Supreme Court's language in Reynolds, the rise of increasingly draconian federal polygamy legislation shows that Congress's target was much larger than plural marriage. The statutes, for example, barred people who practiced or believed in these unions from jury service, and barred actual polygamists from holding public office and from voting. ${ }^{26}$

${ }^{24}$ AmERiCAn Heritage Dictionary 1290 (2d college ed. 1985).
${ }^{25}$ U.S. Const. art. III, § 3.
${ }^{26}$ Edmunds Act, Ch 47, 22 Stat. 30 (1882) (repealed 1983). The first statute was the Morill Act of July 1, 1862, ch. 126, 12 Stat. 501 (repealed 1910). It proved hard to enforce, due to difficulties establishing proof of a second marriage without public or church records, uncooperative Mormon witnesses, and Mormon control of the Utah judiciary. GORDON, supra note 16, at 97, 111. In 1874, Congress passed the Poland Act, which imposed federal control over the Utah judiciary by limiting probate court jurisdiction (which Mormons had expanded to include all civil cases), and also empowered federal marshals to serve process for the district and supreme courts. Act of June 23, 1874, ch. 469, 18 Stat. 253 (repealed). The Poland Act also empowered the U.S. Attorney to prosecute all criminal cases in all courts and mandated jury selection procedures. Id. Reynolds was brought right after the Poland Act closed the loopholes that allowed polygamists to evade prosecution under the Morrill Act, and was a test case tailored to challenge the Morrill Act's constitutionality. Reynolds, 98 U.S. 145. Since Mormons polygamy persisted after the Supreme Court issued its opinion in Reynolds, in 1882 Congress passed the Edmunds Act, which imposed civil disabilities on polygamists and facilitated polygamy prosecutions by creating a new offense, unlawful cohabitation, which did not require proof of marriage. Edmunds Act, supra. This new offense was punishable by a maximum fine of $\$ 300$ or six months in prison. Id. The Edmunds Act also authorized courts to exclude prospective jurors for either practicing or believing in polygamy, barred polygamists from voting or holding public office, and created a federal election commission to oversee Utah elections. Id. Congress struck the fatal blow to polygamy in Utah when it passed the Edmunds-Tucker Act in 1887. Edmunds-Tucker Act, ch. 397, 24 Stat. 635 (1887) (repealed 1978). This law eliminated evidentiary obstacles in polygamy prosecutions, allowed the state to compel wives to testify against their polygamous husbands, allowed adultery prosecutions to be instituted by the state rather than the spouse, required registration of every "ceremony of marriage, or in the nature of a marriage ceremony," federalized the probate courts, disinherited the children of polygamists, re-established dower to assert the power of the first wife in a plural marriage, disenfranchised Utah woman, and placed schools, districting, and the territorial militia known as the Nauvoo Legion under federal control. Id. But most importantly, the EdmundTuckers Act reaffirmed the Morrill Act's revocation of the Mormon Church's corporate 
Moreover, they designated the children of such unions illegitimate, seized the Church's property, and revoked the Church's corporate charter. ${ }^{27}$ President Hayes similarly framed the so-called Mormon Question as political. The day he denied George Reynolds' request for clemency, his diary entry unequivocally condemned all aspects of Mormon governance in Utah, listing polygamy as but one of many "evils" sanctioned by the Church:

Now the Territory is virtually under the theocratic government of the Mormon Church. . . . Polygamy and every other evil sanctioned by the Church is safe. . . . Mormonism as a sectarian idea is nothing; but as a system of government it is our duty to deal with it as an enemy to our institutions and its supporters and leaders as criminals. ${ }^{28}$

In short, the legal doctrines that ban polygamy today are artifacts of a nineteenth century view that polygamy was problematic primarily because it was a symptom of a much greater offense: the establishment of a separatist theocracy.

The Mormons fiercely resisted the federal government's efforts to force them to abandon political, economic and social control of Utah, as well as polygamy. Only in 1890, when the Supreme Court upheld the constitutionality of the last statute, which directed the Attorney General to seize the Church's assets and wind down its affairs, did the Church leaders give in. ${ }^{29}$

status and directed the Attorney General to wind up the corporation's affairs and seize Church property. Id.

${ }^{27}$ Id.

${ }^{28}$ Charles Richard Williams, The Life of Rutherford Burchard Hayes 225 \& n.1 (1914) (emphasis added).

${ }^{29}$ Late Corp. of Church of Jesus Christ v. United States, 136 U.S. 1 (1890). The Church gradually rejected polygamy, beginning with an equivocal statement by Church President Wilford Woodruff known as the 1890 Manifesto. CHURCH OF JESUS CHRIST OF THE LATTER-Day SAinTs, Official Declaration No. 1, in DoCtRine \& CovenanTS (1890), available at http://scriptures.lds.org/en/od/1 [hereinafter Official Declaration No. 1]. Woodruff's public announcement of the Church's changed position on polygamy differs from other divine revelations that Church leaders claimed to have received, in that it began, "To Whom It May Concern." The revelation dictating polygamy, in contrast, begins, "Verily, thus saith the Lord." Compare Official Declaration No. 1, supra, with CHuRCH OF JESUS CHRIST OF THE LATTER-DAY SAINTS, DOCTRINE \& COVENANTS § 132 (1843), available at http://scriptures.lds.org/en/dc/132. Moreover, while other revelations command obedience to God's will, the 1890 Manifesto merely declares President Woodruff's intent to "use my 


\section{A. Mormons Questionable from the Outset}

The Mormon Question engaged the nation for the second half of the nineteenth century. ${ }^{30}$ When Mormon president Brigham Young died in 1877, the New York Times published a lengthy front page obituary, and other papers followed suit. ${ }^{31}$ Throughout the forty-year struggle between Mormons and the federal government over polygamy, newspapers in New York, Philadelphia, San Francisco, Cincinnati and other cities reported on the issue. ${ }^{32}$ Magazines such as Puck, The Wasp, and The Judge published cartoons lampooning Mormon polygamy, and an entire genre of melodramatic fiction engaged readers in lurid tales of polygamy's excesses. ${ }^{33}$ When Brigham Young's sixteenth wife, Ann Eliza Young, left him and sued for divorce, she addressed rapt audiences across the nation,

influence” to have Mormons obey federal law and advise them not to enter plural marriage. Official Declaration No. 1, supra. When the Manifesto was issued, the Salt Lake Tribune dismissed it as "nothing more than the personal advice of a visionary old man," a view echoed by one scholar who described it as "milky advice" rather than "meaty revelation." Brian C. Hales, Modern Polygamy and Mormon Fundamentalism: The Generations AfTER THE MANifESTO 53, 57 (2006). Given the centrality of plural marriage for Mormon culture and theology, it is hardly surprising that some Mormons continued to enter plural marriages after 1890, generally with either Church approval or Church officials looking the other way. Id. at 58, 61-63; GoRDON, supra note 16, at 235. Although the Utah State Constitution included a provision rejecting polygamy in order to obtain statehood in 1896, the Church did not unequivocally renounce plural marriage until 1904. In the wake of twoand-a-half years of Senate hearings that revealed the continued practice of polygamy among Mormons, the Church issued the 1904 Manifesto, which explicitly prohibited plural marriages, and threatened those who entered or solemnized them with excommunication. 4 Messages of the First Presidency, 1901-1915 at 84-95 (James R. Clark ed., 1970). In 1908, the Church began publishing the 1890 and 1904 Manifestos along with its other scriptures. Today, Mormons commonly interpret the 1890 Manifesto as God withdrawing the command to practice polygamy, and the 1904 Manifesto as withdrawing permission to practice it. HALES, supra note 29, at 84.

${ }^{30}$ GORDON, supra note 16 , at 3, 14, 29-58.

${ }^{31}$ Death of Brigham Young, N.Y. Times, Aug. 30, 1877, at 1-2. The New York Times obituary occupied a full column of the front page, and nearly two full columns of page two. For a partial list of media from San Francisco, Chicago, and other cities reporting Young's death, see Gary L. Bunker \& Davis Bitton, The Death of Brigham Young: Occasion for Satire, 54 UtAн Hist. Q. 358, 360 (1986). For the Mormon Newspaper's obituary of Young, see Obituary, Deseret Evening News, Aug. 30, 1877, at 2.

\footnotetext{
32 See, e.g., infra note 85 and accompanying text.

${ }^{33}$ GoRDON, supra note 16 , at 3, 14, 29-58.
} 
including President Grant, his wife, and numerous members of Congress. ${ }^{34}$ Although the salacious details of polygamous life informed much discussion of the Mormon Question, ${ }^{35}$ this Article argues that the underlying controversy was more concerned with politics than sexual improprieties.

\section{B. Mormon Treason}

Mormons were infamous almost from 1830, when Joseph Smith founded the Church of Jesus Christ of Latter-day Saints. Its followers quickly became known as Mormons after their sacred text, The Book of Mormon. ${ }^{36}$ Two elements distinguished this new religion from the outset. First, Smith claimed ongoing, direct communication with God directing him to reform Christianity by re-establishing Old Testament rules. ${ }^{37}$ Second, he promptly amplified the power of these divine directives by excommunicating those outside his family who initially testified that they, too, were present when God dictated the Book of Mormon. ${ }^{38}$ More startling still, Smith crowned himself "king” and ran for president in 1844 under a platform he called "theo-democracy.",

${ }^{34}$ Id. at 112 (describing Ann Eliza Young's lecture tour as "one of the most spectacularly successful lecture tours of the nineteenth century"). After the tour, she published an expose of her experiences among the Mormons. ANn ELIZA Young, WifE No. 19, or A Life in Bondage, Being a Complete Expose of Mormonism, AND Revealing the Sorrows, SACRIfices and Sufferings of Women in POlygamy (Kessinger Publishing 2003) (1875).

${ }^{35}$ Abolitionist literature similarly detailed, often in a salacious manner, the sexual degradations suffered by slave women. AMY DRU STANLEY, FROM BONDAGE TO CONTRACT: WAGe Labor, Marriage, AND the MARKet in the Age of Slave Emancipation 27 (1998). On ways that illicit sex serves as both a catalyst and bar to extension of marriage, see Ariela R. Dubler, Immoral Purposes: Marriage and the Genus of Illicit Sex, 115 YALE L.J. 756 (2006).

${ }^{36}$ GoRDON, supra note 16, at 19, 22, 91.

37 Kathryn M. Daynes, More Wives Than One: Transformation of the Mormon MARRIAGE SYSTEM, 1840-1910, at 23-24 (2001).

${ }^{38}$ Id.

${ }^{39}$ GORDON, supra note 16, at 23. Under "theo-democracy" God instructed Joseph Smith of the proper course, which he then relayed to the people he governed. Some evidence suggests that Smith's title was King of the Kingom of Heaven, or King and Ruler over Israel. Michael McConnell et AL., Religion And the Constitution 113 (2d ed. 2006); Gordon, supra note 16, at 265 n. 41. 
What might have passed unnoticed as a crackpot gesture in one of the many new religious movements cropping up in the early nineteenth century instead attracted considerable enmity. Neither Shakers, who practiced gender equality and celibacy, nor Oneida perfectionists, who practiced a form of non-monogamy they called "complex marriage," exercised the Mormons' economic or political clout. ${ }^{40}$ Mormons' intense evangelism, coupled with doctrines under which Church members ceded control of their everyday lives as well as their property to the Church, made them a large and ever-expanding religious community that took over towns they occupied. ${ }^{41}$ Their political, economic, and social insularity took various forms, including bloc voting, forming their own militia, and doing business only with other Mormons. ${ }^{42}$

Anti-Mormon sentiment drove them to Utah in the late 1840s, where they hoped to implement their separatist theology. ${ }^{43}$ When they tried to indelibly mark the Territory as Mormon by asking Congress to name it "Deseret" after a word in the Book of Mormon meaning "honeybee," Congress refused. ${ }^{44}$ Congress also significantly cut it down from the size requested (which would have represented fully one sixth of the United States). ${ }^{45}$ Mormons did retain control over the Territory's economy through institutions such as the Zion's Cooperative Mercantile Institution (ZCMI), a Church-controlled department store that paid employees in company scrip that ZCMI sellers honored, keeping currency within the Mormon

\footnotetext{
${ }^{40}$ Lawrence Foster, Religion and Sexuality: Three American Communal EXPERIENCES OF THE NINETEENTH CENTURY (1981).

${ }^{41}$ GoRDON, supra note 16, at 24.

42 The New York Times article at Brigham Young's death described the complete control of Church leaders: "Every man had a vote, but all were supposed to vote by direction and counsel of the Lord, through His prophet, Brigham Young. Socially, the Mormons were no better off than a horde of peasants, bound to obey the bidding of suzerain.” Death of Brigham Young, supra note 31, at 2. For a discussion of Mormon resistance to Joseph Smith's ever-increasing powers, see DAYNES, supra note 37, at 33. The Mormons who remained in the Church justified their separatism with a millennial theology that following their church doctrines would reform Christianity in preparation for the soon-to-occur Second Coming. Id. at 21.

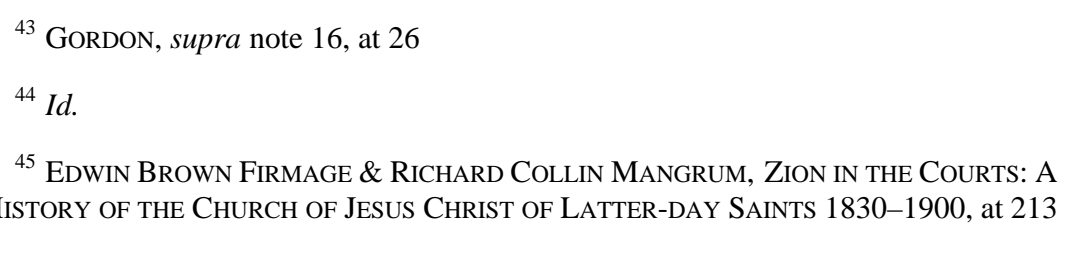
Legal History of THE CHURCH OF JESUS CHRIST OF LATTER-DAY SAINTS 1830-1900, at 213 (1988).
} 
community. ${ }^{46}$ Similarly, the Church experimented with communal living through a form of Christian communism it called the United Order, under which members deeded their property over to the Order, and received back the right to use it as long as they returned any surplus to the Order. ${ }^{47}$

Mormon leaders also controlled all three branches of the Territorial government. In addition to controlling the territorial courts, the Church established separate Church courts for disputes among Mormons. ${ }^{48}$ The Mormon-controlled legislature, for its part, tailored legislation to conform to Mormon doctrine. One statute provided that church decisions regarding marriage "could not be legally questioned," 49 another implemented the Mormon Church's antipathy to legalism by rejecting common law because equitable principles aligned better with Mormon doctrine, and a third statute deprived attorneys of the right to collect their fees to discourage the filing of legal claims. ${ }^{50}$ In the Executive Branch, Mormon president Brigham Young presided as Governor. ${ }^{51}$ As Mark Twain quipped, "the petrified truth is that Utah is an absolute monarchy and Brigham Young is king.",52

The federal government engaged in a prolonged campaign against this separatism'. The military aspect of that campaign concluded with Young giving up the governorship in 1858 after losing an armed conflict with federal troops called the Mormon War. ${ }^{53}$ President Buchanan dispatched three thousand troops to Utah in the summer of 1857 to quell Utah's rebellion. ${ }^{54}$ On September 14, 1857, Young tried to bar federal troops from the Territory, declaring,

${ }^{46}$ Utah, like much of the west, faced perennial shortages in U.S. currency in the nineteenth century. Leonard J. Arrington, Banking Enterprises in Utah, 1847-1880, 29 Bus. Hist. ReV. 312 (1955); Leonard J. Arrington, The Mormon Tithing House: A Frontier Business Institution, 28 Bus. Hist. REV. 24 (1954).

${ }^{47}$ P.A.M. Taylor \& Leonard J. Arrington, Religion and Planning in the Far West: The First Generation of Mormons in Utah, 11 ECON. HIST. REV. 71, 72-73 (1958).

${ }^{48}$ Firmage \& MANGRUM, supra note 45 , at 25-47.

${ }^{49}$ GORDON, supra note 16, at 26.

${ }^{50}$ Id. at 26, 74; FIRMAGE \& MANGRUM, supra note 45, at 218.

${ }^{51} I d$. at 26.

52 Richard White, It's Your Misfortune and None of My Own: A New History OF THE AMERICAN WEST 169 (1991) (quoting Twain's repetition of a traveler's description of Utah).

${ }^{53}$ Gordon, supra note 16, at 60-62.

${ }^{54}$ Id.; Death of Brigham Young, supra note 31, at 2. 
This people are free; they are not in bondage to any government on God's footstool. We have transgressed no law ... . as for any nation's coming to destroy this people, GOD ALMIGHTY BEING MY HELPER, THEY CANNOT COME HERE., 55

Two weeks later, on September 29, Young reiterated his resistance to federal troops by writing to a U.S. Army Colonel, "By virtue of the authority thus invested in me [as governor of Utah], I have issued and forwarded to you a copy of my proclamation forbidding the entrance of armed forces into this territory. This you have disregarded. I now further direct that you retire forthwith from the territory." ${ }^{56}$ Brigham Young put some of his threats into action.

The Nauvoo Legion burned federal supply trains and two federal forts on their way to Utah. ${ }^{57}$ Tensions escalated further after the Mountain Meadows Massacre, in which Mormons and Indians murdered some 127 Arkansans traveling through Utah in September 1857. ${ }^{58}$ The federal government placed Utah under martial law, and only the onset of a severe winter prevented federal troops from battling the Mormon army of $2500 .^{59}$ By acting as if he led an independent country, Young posed a secessionist threat to the Union. ${ }^{60}$ In the late 1850 s, these threats were particularly powerful as tensions between the North and South escalated in the build up to the Civil War. Moreover, access to the western trails running through Utah gave Young the power to significantly limit access to the West Coast. ${ }^{61}$ The federal government responded to the Mormons' secessionist threat by indicting Young and sixty followers for treason. ${ }^{62}$

${ }^{55}$ Ray B. West, Kingdom of the Saints: The Story of Brigham Young And THE MORMONS 256 (1957) (emphasis in original).

${ }^{56}$ Id. at 258.

${ }^{57}$ FiRMAGE \& MANGRUM, supra note 45, at 244.

58 Juanita Brooks, The Mountain Meadows Massacre 146 (new ed. 1966).

${ }^{59}$ Id. at $74-75$.

${ }^{60}$ Firmage \& MANGRUM, supra note 45, at 213; White, supra note 52, at 169, 170. Mormons also flirted with approaching Britain and Mexico for support. DAYNES, supra note 37 , at 37 .

${ }^{61}$ Firmage \& MANGRUM, supra note 45, at 213

62 Id. at 244; James Willard Hurst, The Law of Treason in the United STATES: COLLECTED ESSAYS 264 (1971). 
While it was not the first treason prosecution against Mormons, it was the most firmly grounded in law. Mormons could reasonably claim self-defense in Missouri's and Illinois's 1838 and 1844 treason prosecutions against Mormon founder Joseph Smith, but even the official history of the Mormon Church concedes that "technically speaking," the Mormons levied war against the United States in the Mormon War. ${ }^{63}$ President Buchanan pardoned the defendants in 1858, on the condition that Young and his followers "submit themselves to the authority of the federal government."64 While the new, non-Mormon governor declared in June 1858 "peace is restored to our Territory,"65 the truce was fragile. The continued hostilities were evident in Young's declaration after signing the pardon: "If a man comes from the moon and says he will pardon me for kicking him in the moon yesterday, I don't care about it. I'll accept of his pardon.,"66

The taint of treason pervaded discussions of Mormon polygamy in all three branches of government. Another "treason and rebellion" prosecution occurred in 1870, involving people close to George Reynolds, who would be the defendant in the case testing the constitutionality of the federal criminalization of bigamy through the Morrill Act. ${ }^{67}$ Mormons resisted the federally appointed governor's challenge to their control of the Nauvoo Legion in an action known as the Wooden Gun Rebellion. ${ }^{68}$ While Reynolds himself escaped prosecution, eight Nauvoo Legion officers from Reynolds's regiment were charged with "treason and rebellion."69 Again, in 1871, federal prosecutors in Idaho sought to charge Brigham Young with treason for "lewd and lascivious cohabitation," in violation of a Territorial

${ }^{63}$ Id. In Missouri, defendants escaped (possibly with the cooperation of their captors). 4 B.H. RoBerts, COMPREHENSIVE History OF THE CHURCH OF JESUS CHRIST OF LATTER-DAy SAINTS 411 (photo. reprint 1965) (1957). See also NELS ANDERSON, DeSERT SAINTS 188 (1942).The Illinois prosecution was truncated by Smith’s murder by a mob after his arrest. Id.

${ }^{64}$ Proclamation of Apr. 6, 1858, in 5 A Compilation of Messages \& PAPERs of THE PRESIDENTS 493, 495 (James D. Richardson comp., 1897).

${ }^{65}$ HuRst, supra note 62, at 159.

${ }^{66}$ Edward W. Tullidge, The History of Salt LaKe City and Its Founders 136 (1886).

${ }^{67}$ For a discussion of the four federal antipolygamy statutes, see supra note 26.

681 ANDREW JENSON, LATTER-DAy SAINT ENCYCLOPEDIA 208 (1901).

${ }^{69}$ Bruce Van Orden, Prisoner for Conscience's Sake: The Life of George REYNOLDS 32 (1992); JENSON, supra note 68, at 208. 
statute. ${ }^{70}$ Judge McKean explicitly framed the prosecution as vanquishing "polygamic theocracy," declaring:

While the case at the bar is called "The People versus Brigham Young," its other and real title is "Federal Authority versus Polygamic Theocracy." The government of the United States, founded upon a written constitution, finds within its jurisdiction another government - claiming to come from God . . . whose policies and practices, are, in grave particulars, at variance with its own. The one government arrests the other, in the person of its chief, and arraigns it at this bar. A system is on trial in the person of Brigham Young. Let all concerned keep this fact constantly in view; and let that government rule with out rival which shall prove to be in the right. ${ }^{71}$

Similarly, in 1886, seven years after Reynolds lost in the Supreme Court, and a year before Congress passed its fourth and final antipolygamy statute, Mormon leader John W. Taylor was charged in Idaho Territory with inciting rebellion against the laws of the United States by encouraging Mormons to practice polygamy. ${ }^{72}$

The other branches of government similarly framed the Mormon Question as political treason. One legislator, Vermont Senator George Edmunds, described polygamy as a "crime against the political institutions of our country."73 Even Stephen A. Douglas, legendary supporter of states’ rights, denounced Mormons as "a pestiferous disgusting cancer . . . alien enemies and outlaws engaging in treasonable, disgusting and bestial

${ }^{70}$ Ray B. West, Kingdom of the Saints: The Story of Brigham Young And THE MORMONS 320 (1957).

${ }^{71} I d$.

72 Free Speech, Ogden Daily Herald, Aug. 19, 1886, at 2; A Precious Document: The Indictment Against Apostle John W. Taylor, OgDen DAILY HeRALD, Nov. 2, 1886, at 4. The case was continued until the following April. Deseret NEws, Nov. 17, 1886, at 1. A Utah Territorial Court similarly melded treason to bigamy charges against one William Felstad in 1886. To the Penitentiary, Deseret News (Weekly ed.), Sept. 22, 1886, at 1 . According to the Deseret News, "the Judge said that a man had no right to recognize in the covenants or laws of any organization a higher allegiance than that which he owed to the government. Treason consisted in an attempt to overthrow the laws of the government. The defendant, in refusing to promise obedience to those laws, sought to overthrow them.” Id. 285.

${ }^{73}$ George F. Edmunds, Political Aspects of Mormonism, HARPER’s, Jan. 1881, at 
practices.” 74 Speaking for the Executive Branch in 1881, President Garfield's Inaugural Address asserted that the Mormon Church should not "be safely permitted to usurp in the smallest degree the functions and powers of the National Government.",75

What kept the federal government from eradicating Mormon separatism through treason prosecutions? Maybe, in light of the Civil War, the federal government wanted to consolidate its power and the Union without directly raising the thorny issues of local control just barely resolved through that war. Maybe polygamy was winnable, while jurisdictional, factual, or doctrinal barriers weakened a treason claim. ${ }^{76}$ In any case, the federal decision to prosecute Mormons for polygamy rather than treason does not eradicate the role of treason in the case. ${ }^{77}$

That close link between polygamy and political treason held far beyond the halls of government. The following materials use political cartoons to demonstrate the interweaving of political and racial treason in popular discourse, explicating the images with medical and other scholarly materials of the day.

An 1882 cartoon in the popular humor magazine Puck is typical. Titled "The Carrion Crow in the Eagle’s Nest," the Puck cartoon appeared the same year Congress enacted its third antipolygamy statute. ${ }^{78}$

\footnotetext{
${ }^{74}$ WHITE, supra note 52, at 168 . While most states' righters joined the rest of the nation in condemning polygamy, the close analytical relationship between slavery and polygamy led the Mormon Church to hire George Washington Biddle, an ardent Democrat, to represent Reynolds in the Supreme Court. GoRdon, supra note 16, at 119. Biddle argued that the 1857 Dred Scott case, which held that Congress's "powers over person and property" did not extend to the Territories (thus mandating the return of a slave to his owner), similarly limited Congress's power to eradicate slavery's “twin,” polygamy. Id. at 123-24.

75 James Garfield, President of the United States, Inaugural Address (Mar. 4, 1881).

${ }^{76}$ Firmage \& MANGRUM, supra note 45, at 245.

77 Similarly, when the government sues the Mob for tax evasion, the underlying offense bleeds through.

78 The Carrion Crow in the Eagle's Nest, PUCK, Jan. 25, 1882, reprinted in GARY L. Bunker \& Davis Bitton, The Mormon Graphic Image, 1834-1914, at 48 (1983); GoRDON, supra note 16, at 136 .
} 
[Vol. 19:2

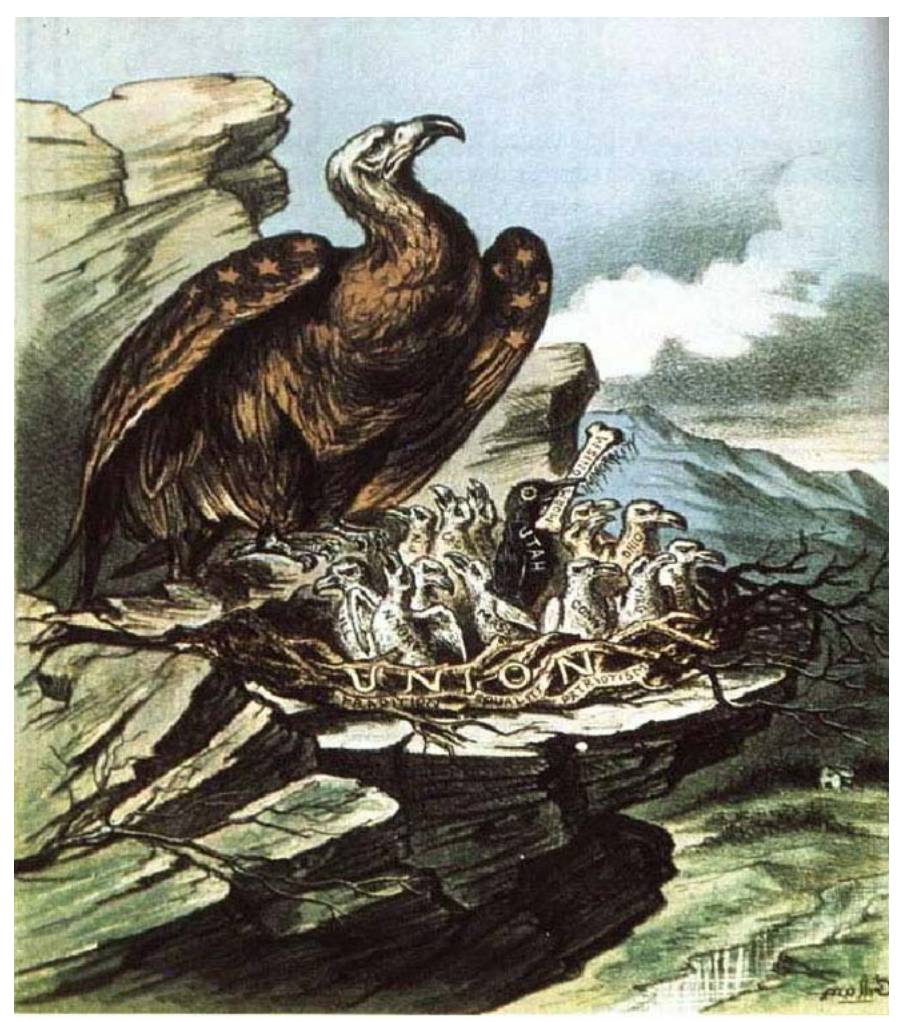

The Carrion Crow in The Eagle's Nest, Puck, Jan. 25, 1882

The cartoon depicts a fierce eagle, stars and stripes on its wings representing the United States, protecting its nest, which is labeled "union." Inside the nest are eaglets, all White, each labeled for a state. A "carrion crow" labeled "Utah" rises up in their midst, clutching a bone labeled "Mormonism." Three things bear mentioning. First, the cartoon appeared less than a generation after the end of the Civil War, when most viewers would situate its imagery within the national catastrophe of Confederate Secession. Second, it labeled the bird representing Utah as "Carrion Crow." This crow gets its name from its habit of eating dead animals, making its presence in the caption depict Mormonism as a harbinger of death. Moreover, the birds representing the other states seem to be eaglets, the same species as the eagle, while the crow represents a new species, black, holding its own bone and defiantly turning its back on the mother. In contrast, the eaglets either beg for food or look out as if guarding the nest. Integrating these elements, we can interpret the single Black crow among White eaglets as signaling political defiance against the Union, 
racial grounds for denying Utah statehood, and miscegenation. In the decades after Civil War, intense legal, political, and social battles raged over the citizenship of African Americans, generally resulting in severely limited social and political rights for the freed slaves. Consequently, this cartoon, published in that climate, seems to reference both the Civil War and the place of Blacks in America in the wake of emancipation. The Black crow symbolizing Utah, nestled among White eaglets symbolizing the other states, is akin to the Confederacy seceding to protect its own peculiar domestic institution. In this view, depicting Utah as a carrion crow would justify denying "black" Utah membership in the Union just as the Black Codes and other measures denied African Americans full citizenship. ${ }^{79}$ The mix of white and black baby birds in the cartoon also raises the specter of miscegenation, which animated the Black Codes. ${ }^{80}$

The nation was struggling over the constitutionality of miscegenation laws at the very moment that Mormon polygamy attracted intense debate and regulation. Many southern states repealed their miscegenation statutes shortly after the Civil War, reasoning that the Civil Rights Act of 1866 and the 14th Amendment to the Constitution allowed African Americans to contract marriages just like White citizens. ${ }^{81}$ However, they reinstated miscegenation laws in the 1880s and 1890s, claiming that the ban on interracial marriage did not violate principles of equal protection, since it prevented both Blacks and Whites from marrying outside their race. ${ }^{82}$ Indeed, in 1883, a year after "The Carrion Crow," the U.S. Supreme Court used this rationale to uphold miscegenation laws in Pace v. Alabama. ${ }^{83}$ As the sole Black child among White siblings, the crow signifies multiracial families produced by race-mixing. By linking Mormon polygamy with political treason and racialized political and familial degeneration, the cartoon triggers explosive issues far beyond polygamy as a marital variation.

Mormon leadership did little to calm these fears. An 1870 sermon by Brigham Young is typical. He claimed polygamous husbands' power extended beyond the family to "my neighbors and the people around me,"

\footnotetext{
${ }^{79}$ Gross, supra note 17 , at 38, 139.

${ }^{80}$ PAsCOE, supra note 3, at 6-7.

${ }^{81}$ Id. at 115.

${ }^{82}$ Id. at 68.

83106 U.S. 583 (1883).
} 
referring to himself as a "king" who controlled his wives and children by "dictates":

If I am controlled by the Spirit of the Most High, I am a king, I am supreme so far as the control of self is concerned; and it also enables me to control my wives and children . . . They will be perfectly submissive to my dictates. ${ }^{84}$

A Mormon bishop's statement reported in a San Francisco newspaper similarly confirmed Americans' worst fears about Mormon political aims: "Utah will be admitted as a polygamous State, and the other Territories we have peacefully subjugated will be admitted also. We will then hold the balance of power, and will dictate to the country." 85 It is hardly surprising that many Americans heard treason in this kind of talk.

This treason thread running throughout nineteenth century discussions of Mormon polygamy helps us make sense of the Court's assertion in Reynolds that polygamy "fetters its members in stationary despotism." ${ }^{86}$ But the Supreme Court in Reynolds did not stop there, and also linked polygamy with "Asiatic and African peoples.",77 "The Carrion Crow" cartoon provides one example of the braided political and racial elements of Mormon treason. The following Section further elaborates the racialized arguments regarding Mormon treason made in other cartoons of the day, medical opinion, melodramatic fiction, as well as the parallel course of antipolygamy legislation and Chinese Exclusion legislation.

\section{MORMON POLYGAMY AS RACE TREASON}

The racial aspect of antipolygamy legislation charges White Mormons with causing the physical and moral degradation of their race by engaging in a marital practice that was "unnatural" for them, even as it was "natural" for the purportedly backward, lascivious people of Asia and Africa. But before reconstructing those arguments and illustrating them with cartoons of the day, we must address two preliminary objections.

\footnotetext{
${ }^{84}$ GoRDON, supra note 16 , at 105.

${ }^{85}$ Id. at 170 (quoting Angelina French Newman, Woman Suffrage in Utah, at 5 in Miscellaneous Documents, 49 Cong., 1 Sess., S. Doc. 122 (June 8, 1886)).

${ }^{86}$ Reynolds v. United States, 98 U.S. 145, 165-66 (1879).

${ }^{87}$ Id. at 145 .
} 


\section{A. Preliminary Objections}

\section{Haven't the Mormons Always Been White?}

It may seem odd to depict Mormons as Black or Asian when they were almost entirely White. Indeed, while Mormon settlers married Native American women on occasion, ${ }^{88}$ Mormons excluded African-Americans from full church participation until $1978 .^{89}$ This Whiteness, according to many antipolygamists, was precisely the problem.

Antipolygamists did not see Blacks “acting Black” as a problem, since that supposedly reflected natural differences between races. But Whites following practices attributed to Asians or Blacks undermined the premises justifying white supremacy. The links between race and Mormon polygamy in many nineteenth century Americans' minds were both tight and complex. The closeness of the link is apparent in the common discussion of slavery and polygamy as the "twin relics of barbarism.",90 This phrase, and the linkage of the two "peculiar institutions," was so widespread that the Republican Party's 1856 Presidential Platform pledged to eradicate the "twin relics of barbarism" in the territories. ${ }^{91}$ Scholars have noted the link between the "twin relics," ${ }^{22}$ but have not mapped the complexity of racial motivations for antipolygamy law. Here, I argue that the racialized strand of antipolygamist discourse demonstrates that abolition and antipolygamy rhetoric assumed diametrically opposed postures in relation to white supremacy. Abolitionists sought to decrease racial hierarchy through emancipation. Antipolygamists, in contrast, sought either to maintain or reinstate white supremacy, perhaps hoping to limit the scope of slaves' emancipation by equating racial mixing with disorder, and, conversely, associating racial hierarchy with domestic political order. In

\footnotetext{
${ }^{88}$ DAYNES, supra note 37, at 11.

${ }^{89}$ Jessie L. Embry, Black SAints in a White Church: CONTEMPORARy African AmERICAN Mormons 1 (1994); O. Kendall White, Jr. \& Daryl White, Abandoning an Unpopular Policy: An Analysis of the Decision Granting the Mormon Priesthood to Blacks, 41 SoC. ANALYSIS 231 (1980).

${ }^{90}$ GoRDON, supra note 16, at 55.

${ }^{91} \mathrm{Id}$. at 13 .

92 See, e.g., id. at 13, 55, 62; Nancy Bentley, Marriage as Treason: Polygamy, Nation, and the Novel, in The Futures OF AMERICAN STUDIEs 341, 344-50 (Donald E. Pease \& Robyn Wiegman eds., 2002); FIRMAGE \& MANGRUM, supra note 45, at 129; Talbot, supra note 4 , at $315-58$.
} 
other words, many nineteenth century Americans condemned slavery for harming Blacks, and polygamy for harming Whites.

\section{But They're Just Cartoons}

One might argue that they are just cartoons and were never meant or interpreted as seriously as this Article suggests. True. But humor tells us a lot about social conventions, and it helps us read cases and statutes in light of the culture of the time. Nineteenth century Americans read political magazines-Harpers, The Judge, and Puck, for example-in general stores, blacksmith shops, taverns, or wherever they gathered. Literate people read to others, and everyone understood the cartoons. The cartoons analyzed here, therefore, likely reflected and helped shape political opinions, and ultimately, policy. Moreover, readers' humor tells us what they found incongruous, like a dog commanding its master to "sit." If nineteenth century viewers laughed at the stock features of antipolygamy cartoonsmulti-racial families, powerful women, and effeminate men-that laughter was like our chuckle at the headline "Man Bites Dog." Looking at these cartoons together with other primary sources reveals an encrypted caption below most of the cartoons that reads, "Too much choice leads to chaos; let's return to the certainties of status."

\section{B. Mormons as Racial Others}

Again and again, commentators from high culture (media and legal experts mainly) and popular culture (cartoonists and authors of magazine articles) portray Mormons as barbaric, lascivious, despotic, disorderly, foreign, Black, Asian, and/or childish. Perhaps the best example "Uncle Sam's Troublesome Bedfellows,” published in the Wasp just a month after the Court announced its decision in Reynolds. ${ }^{93}$

${ }^{93}$ Uncle Sam's Troublesome Bedfellows, THE WASP, Feb. 8, 1879, reprinted in BUNKER \& BITTON, supra note 78, at 79. 


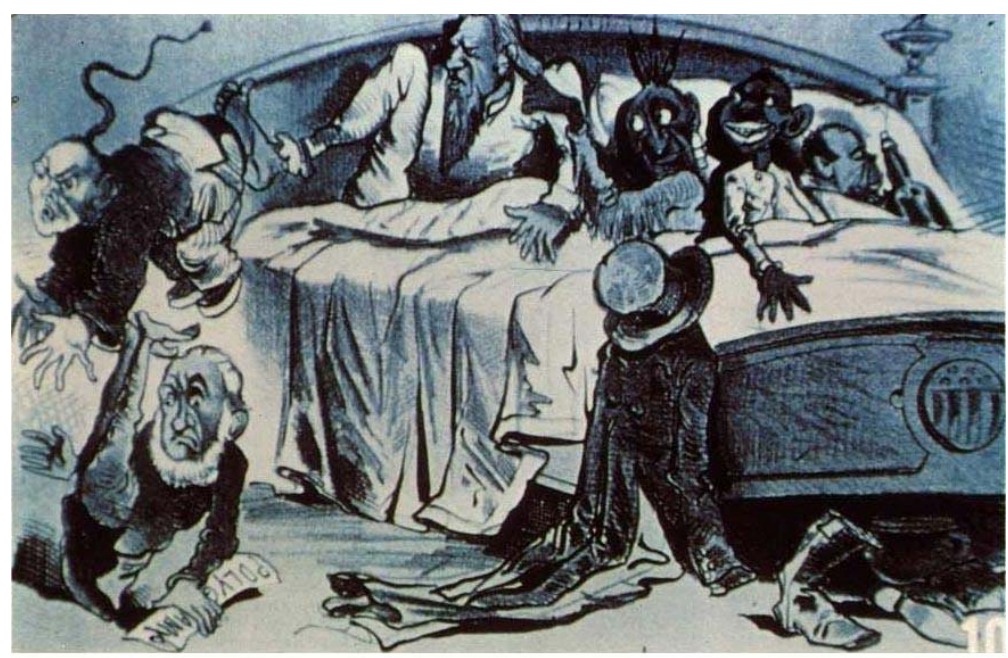

Uncle Sam's Troublesome Bedfellows, THE WAsp, Feb. 8, 1879

Uncle Sam, representing the country, shares a big bed with three "troublesome bedfellows," and is in the process of kicking out two others. Lumping Mormon, Chinese, Native American, Black, and Irish figures as "troublesome bedfellows" served two purposes. First, it suggested a common debasement of all five groups. Second, it distinguished all of them from Uncle Sam. Edward Said explains, in the colonial context, how designating people or groups as "problems" rather than human beings determined their defeat from the outset:

Along with all other peoples variously designated as backward, degenerate, uncivilized, and retarded, the Orientals were viewed in a framework constructed out of biological determinism and moral-political admonishment ... Orientals were rarely seen or looked at; they were seen through, analyzed, not as citizens, or even people, but as problems, to be solved or confined or . . . taken over. The point is that the very designation of something as Oriental involved an already pronounced evaluative judgment, and ... an implicit program of action. Since the Oriental was a member of a subject race, he had to be subjected. ${ }^{94}$

Indeed, the cartoon depicts subjugation of both Mormon and Chinese figures through Uncle Sam kicking both out of bed. The Mormon polygamist's bottom is about to hit the floor. The paper he clutches, labeled "polygamy," may simply announce the reason for his ejection, or perhaps

\footnotetext{
${ }^{94}$ SAID, supra note 10 , at 3 (emphasis added).
} 
also refers the government's formal declaration of that policy through the Reynolds opinion weeks earlier. The Chinese figure's ponytail labels him, and his placement mid-air may reflect Uncle Sam's not-yet-completed exclusion of Chinese immigrants. As of February 1879, the date of the cartoon, Congress was in the midst of its multi-stage exclusion of Chinese immigrants.

That very same month, Congress was debating the Fifteen Passenger Bill, which prohibited more than fifteen Chinese passengers from being brought on any steamship to the United States. ${ }^{95}$ Maine Senator James Blaine's arguments supporting the Bill framed the issue as a racial contest for dominance of the American West: "either the Anglo-Saxon race will possess the Pacific slope or the Mongolians will possess it." ${ }^{\text {" }}$ Blaine escalated the "us/them" rhetoric in a widely reprinted letter to the New York Tribune a week later, condemning Chinese immigration as "vicious,' 'odious,' 'abominable,' 'dangerous,' and 'revolting,"” and comparing the Chinese to an infection that would bring "'moral and physical disease, destitution, and death." "97 Blaine’s view prevailed. On February 22, 1879, a month after Reynolds was announced and two weeks after the publication of "Uncle Sam's Troublesome Bedfellows," Congress passed the Fifteen Passenger Bill. ${ }^{98}$

Returning to the cartoon, Uncle Sam's other "troublesome bedfellows” remained, at least for the moment: a Native American sticking a long finger in Uncle Sam's ear; a Black figure grinning foolishly; and a simian Irishman clutching a bottle. The simian Irishman deserves brief note, since nineteenth century understandings of Irish people as Black show how

958 Cong. REC. 1748, 1796-97 (1879) (debating H.R. 2423 on Feb. 22, 1879). On March 1, 1879, President Hayes vetoed the Bill, explaining that it violated the Burlingame Treaty that allowed free Chinese immigration. ANDREW GYORY, ClOSING THE GATE: RACE, POLITICS, AND THE CHINESE EXCLUSION ACT 218 (1998). Congress accordingly amended the Burlingame Treaty in November of 1880 to allow the United States to limit or suspend, but not prohibit, Chinese immigration if the United States decided that doing so was in the country's best interest. Id. The following year the Senate ratified the Angell Treaty, solely "to give the United States the right to restrict Chinese immigration." Id. For further discussion of barriers to Asian American citizenship, see Leti Volpp, "Obnoxious to Their Very Nature:” Asian Americans and Constitutional Citizenship, 8 AsIAN L. J. 71 (2001)

968 CONG. REC. 1294, 1301 (1879) (Feb. 14, 1879). See also GYORY, supra note 95, at 3 .

${ }^{97}$ Gyory, supra note 95, at 3-4 (quoting James Blaine, Editorial, Chinese Immigration, N.Y. TRIB., Feb. 24, 1879, at 4).

98 H.R. 2433, 45th Cong. (1879). For an argument that Chinese Exclusion constituted American legal Orientalism, see Ruskola, supra note 11, 215-16. 
Whiteness was a culturally constructed insider status designating civic membership that could be denied to unpopular Whites. ${ }^{99}$ An 1876 cover of Harper's Magazine featured a Thomas Nast cartoon titled "The Ignorant Vote: Honors are Easy," showing an emancipated slave and an Irishman, equating the two by placing them on a scale facing one another: ${ }^{100}$

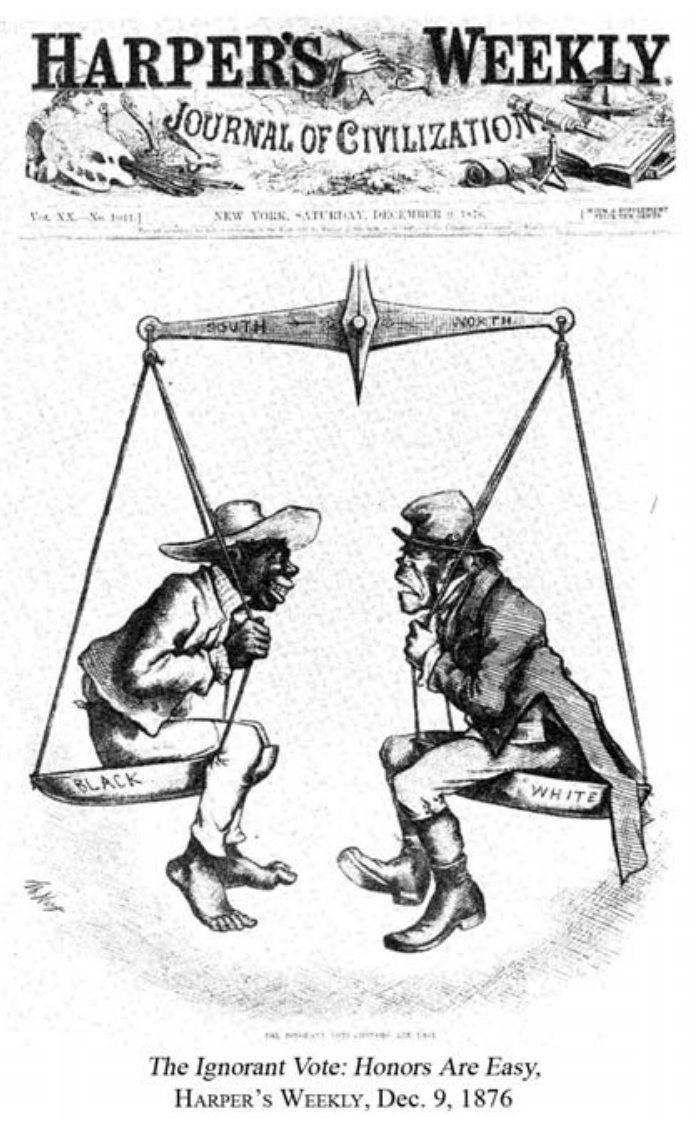

Similarly, Puck magazine ran a James A. Wales cartoon in November 1880 titled “An Irish Jig." ${ }^{101}$ It portrayed a wild Irishman with simian features, dancing and brandishing a dagger toward a concerned Uncle Sam and John Bull (who personified England):

\footnotetext{
${ }^{99}$ Bentley, supra note 92 , at 358.

100 Thomas Nast, The Ignorant Vote: Honors Are Easy, HARPeR's WeEKLy, Dec. 9,
} 1876.

101 James A. Wales, An Irish Jig, PuCK, Nov. 3, 1880. 
[Vol. 19:2

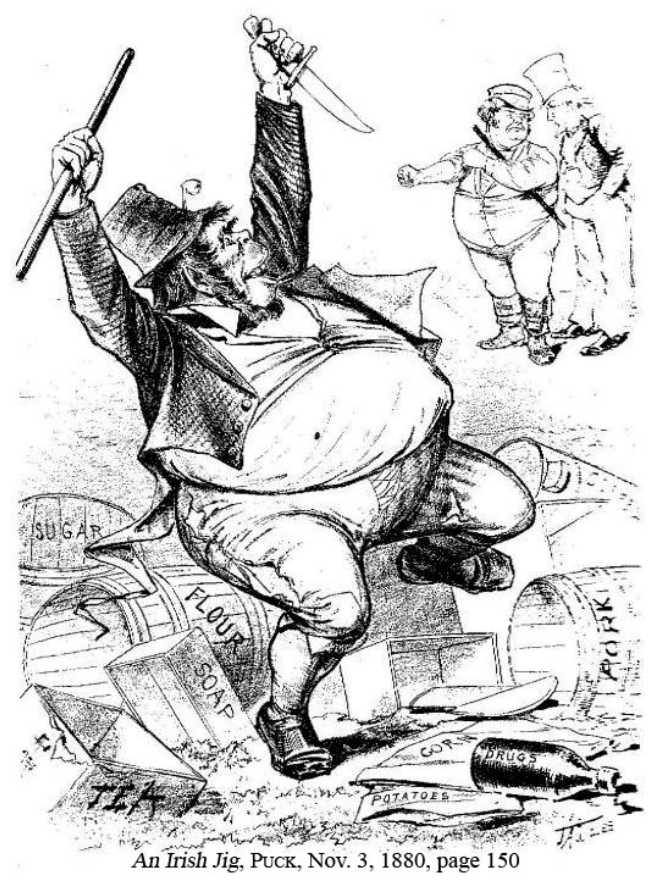

Taken together, these cartoons shed light on Irish as Black, in the nineteenth century popular imagination. Moreover, highlighting the denigration—which literally means "blackening" ${ }^{102}$ —of both White Mormons and Irish people in the late nineteenth century demonstrates how many Americans then linked race and nationality. "We," meaning Whites descended from Northern Europe (but not Ireland), determined the terms of "their" (Chinese, Native American, African American, Irish, and Mormon) participation in American democracy. Given this power disparity, "we" should prevail in any contest with "them." But lumping marginalized groups as "them" tells only part of the story. Deeper analysis reveals more sophisticated machinations.

\section{Polygamy Causing Racial Degeneration}

Political, medical, and popular sources repeat the theme that Mormon polygamy created a new race of effete men, ungovernable hordes of women and children, and primitive characteristics like licentiousness, laziness, childishness, and submissiveness to despotism. In this teleological

\footnotetext{
102 Merriam Webster's Collegiate Dictionary 333 (11th ed. 2007).
} 
perspective, civilization rose "like the sun in the farthest reaches of the East and advanced progressively westward," leaving behind China, India, and the Arab world as cultures "past their glory." 103 The metaphor, grounded in a natural phenomenon, created a framework for the West's inevitable and innate superiority. Within this intellectual rubric, parity between Eastern and Western cultures was as unlikely as the sun changing its course.

The materials examined below link Mormon polygamy with fears of White racial degeneration that produced a naturalized discourse linking a person's condition of birth to a "natural" form of marriage: polygamous if "Asiatic or African," and monogamous if White. Purported experts reporting on the exotic practice of Mormon plural marriage often spoke of polygamy's degenerative effect on children born into plural marriages. ${ }^{104}$ Focusing on children complemented the implicit temporality of civilization marching from East to West (from Asia to Whiteness) as inevitably as afternoon follows morning, because a person's life followed a similarly predictable course. Children, in this view, personify the future, so that their actions in the cartoons seem to predict polygamy's effect on coming generations, and indeed the nation's future.

One territorial official, Benjamin Ferris, voiced those concerns in an 1854 Report to Congress, declaring that polygamy "belongs now to the indolent and opium-eating Turks and Asiatic, the miserable Africans, the North American savages, and the latter-day saints." 105 As a consequence, Farris contended, the results of polygamy would shortly "manifest in the rapid degeneracy of races." 106 Samuel Bowles, an abolitionist journalist, also linked polygamy with degeneration in his 1865 travelogue Across the Continent: "It is safe to predict that a few generations of such social practices will breed a physical, moral, and mental debasement of the people most frightful to contemplate." ${ }^{107}$ An 1857 article entitled "Scenes in an American Harem” echoed this view by diagnosing both racial and gender

103 John KuO Wei TCHen, New York Before Chinatown: ORIENTALISM AND THE SHAPING OF AMERICAN CULTURE 1776-1882, at Xvi (1999).

104 Talbot, supra note 4, at 334.

105 Benjamin G. Ferris, Utah and the Mormons: The History, Government, Doctrines, Customs, and Prospects of the Latter-Day Saints, From Personal Observation During a SiX-Months’ Residence at Great Salt LaKe City 247 (1854).

${ }^{106}$ Id. at 247; Talbot, supra note 4, at 334.

107 Talbot, supra note 4, at 334-45 (quoting SAmUEL Bowles, Across THE Continent: A Summer's Journey to the Rocky Mountains, The Mormons, And the PACIFIC STATES, With SPEAKER COLFAX 124 (1865)). 
deterioration of Whites through "very weak-minded" Mormon women and linking the fate of the (White) nation to Mormonism by asserting "Salt Lake polygamy must rob the Anglo-Saxon females of their boast of intellect, and the age of its vaunt of progress."108

Hugely popular antipolygamy novels echoed these themes of racialized and gendered degeneration. Maria Ward's novel The Mormon Wife, reissued repeatedly after its 1855 publication, typified the genre. ${ }^{109}$ It cast White Mormon wives as slaves, luridly detailing their capture, punishment, and submission. ${ }^{110}$ Mary Hudson's 1880 novel Esther the Gentile dramatically asserted that "Mormon women are slaves to their husbands, concubines to their religion, and martyrs to despotism as immoral

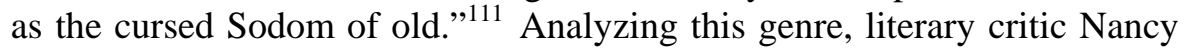
Bentley asserts that "monogamy for white wives . . . approach[ed] something of a racial birthright and a fact of natural history." 112 These fictional accounts typically demonstrated the impact of polygamy on White female bodies through their immediate collapse after entering a plural marriage. Bentley explains, "Though they formally assent, in the conventional resolution to the wedding scene first wives regularly faint after speaking their consent, the first sign of an illness that usually kills or drives them mad after this injury to their womanhood."

These fictional accounts of polygamy's dramatic impact on White women's bodies exemplify the larger focus on the bodies of Mormon polygamists. Medical research purported to identify physical peculiarities of children born of polygamous unions. The racial focus of these "scientific" 1857, at 649).

${ }^{108}$ Id. at 334 (quoting, Scenes in an American Harem, HARPERs WEEKLY, Oct. 10,

\footnotetext{
${ }^{109}$ Gordon, supra note 16, at 29.

${ }^{110}$ Bentley, supra note 92, at 346.

${ }^{111}$ Id. at 347.

112 Id. at $357-58$.

113 Id. at 349. Barthelow's "scientific” report on Mormon polygamy similarly described the bodily devastation that polygamy caused in White women: "In Eastern life, where it has been a recognized domestic institution for ages, women are prepared for its continuance, and do not feel degraded by their association with it. The women of this Territory, how fanatical and ignorant soever, recognize their wide departure from the normal standard in all Christian countries; and from the degradation of the mother follows that of the child, and physical degeneracy is not a remote consequence of moral depravity." Roberts Barthelow, Hereditary Descent; or Depravity of the Offspring of Polygamy Among the Mormons, 30 DeBow’s ReV. 206, 210 (1861).
} 
findings, understood as a parallel cultural discourse to antipolygamy statutes and case law, shows how often nineteenth century Americans bundled polygamy with both race and gender-based degeneracy.

Medical opinion, boasting unique expertise in bodies, may have proved especially influential in shaping the national view of polygamous Mormons as physically deficient. This discourse was deeply steeped in the scientific racism of the day that served larger social agendas. Alabama gynecologist Dr. J. Marion Sims, for example, sometimes dubbed a founding father of gynecology, developed his expertise in the 1840s by performing experimental surgeries on unanesthetized slaves, contending that Blacks did not feel pain. ${ }^{114}$

Dr. Roberts Barthelow applied this brand of scientific rigor to studying the Mormons. Barthelow developed his skills at so-called scientific classification early in his career while attending the U.S. Troops in Utah during the Mormon War in 1857 and 1858. ${ }^{115}$ He reported his findings to the U.S. Surgeon General, presented them to the Senate, and published them in $1860 .{ }^{116}$ Beginning by noting the "tendency of peculiar institutions ... [to] produce permanent varieties of the peculiar race," Barthelow proceeded to identify what he termed the new Mormon "racial type" in gendered terms of physical and moral weakness:

This condition is shown by the preponderance of female births; by the mortality in infantine life; by the large proportion of the aluminous and gelatinous types of constitution; and by the striking uniformity of the facial expression .... One of the most

114 Harriet A. Washington, Medical Apartheid: The Dark History of MEdical Experimentation on Black Americans from Colonial Times to the PRESENT 65 (2007) ("He claimed that his procedures were 'not painful enough to justify the trouble and risk attending the administration [of anesthesia]' . . . Sims always cited the popular belief that blacks did not feel pain in the same way as whites.”) (footnote omitted).

115 B. Cameron Hardy \& Dan Erickson, “Regeneration-Now and Evermore!”: Mormon Polygamy and the Physical Rehabilitation of Humankind, 10 J. Hist. SEX. 40, 48 (2001).

116 Talbot, supra note 4, at 335. Barthelow's report was reprinted under the title Hereditary Descent, note 113 supra. This publication, reporting an 1860 meeting of the New Orleans Academy of Science, also included commentary criticizing Barthelow's findings as failing to comply with the scientific method. Id. at 207-08. See also CHARLES A. CANNON, The Awesome Power of Sex (1974); Terryl L. Givens, New Religious Movements and Orthodoxy: The Challenge to the Religious Mainstream, 19 FARMS REV. 203 (2007). 
deplorable effects ... is shown in the genital weakness of the boys and young men, the progeny of the peculiar institution."117

Barthelow further explicated his findings in quasi-racial terms, describing the "genital weakness" as evidenced by:

An expression compounded of sensuality, cunning, suspicion, and a smirking self-conceit. The yellow, sunken, cadaverous visage; the greenish-colored eye; the thick, protuberant lips; the low forehead; the light, yellowish hair; and the lank, angular person, constitute an appearance so characteristic of the new race, the production of polygamy, as to distinguish them at a glance. ${ }^{118}$

According to Barthelow, polygamy monkeyed with Whites' natural tendency toward monogamy. ${ }^{119}$ Departing from that norm, in this view, caused the White children of polygamy to evidence characteristics of purportedly backward groups for whom polygamy was "natural."120

Barthelow was hardly alone in these views. Professor C.G. Forshey teamed up with Dr. Samuel Cartwright to publish Barthelow's 1861 Report as part of the proceedings of the New Orleans Academy of Science. ${ }^{121}$ Forshey provided commentary to the Report:

For the female of those oriental and tropical races, practicing polygamy, there is no high intellectual destiny-no aspiration after the pure and beautiful; but a pre-ordained servitude, compatible with their nature, and adapted to the semi-civilization which is the acme of development in the races to which they belong. Extinction, then, is not a tendency of Eastern polygamy, as in the European race of men. It is not a violation of natural law, where the natural instincts in the normal condition of the race do not forbid it. ${ }^{122}$

\footnotetext{
117 Talbot, supra note 4, at 335.

${ }^{118}$ Id. at 335-36 (quoting Surgeon General’s OfFice, Statistical Report

${ }^{119}$ Id.

${ }^{120} \mathrm{Id}$.

${ }^{121}$ Hereditary Descent, supra note 113.

122 Id. at 211. Significantly, the publication includes objections from several members of the New Orleans Academy of Science on the ground that Barthelow's research did not follow scientific method. Id. at 210.
}

302). 
Dr. Cartwright, famous for his works in scientific racism such as Diseases and Peculiarities of the Negro Race, ${ }^{123}$ echoed these concepts of natural mandates, explicitly contrasting the marital (and consequent social, political, and economic) practices of "the inferior colored races" with "the European (or white race of men)":

The fact that the inferior colored races, among whom polygamy is universal, are self-sustaining, proves that is has not the same pernicious influences upon them as on the white race."124

Forshey added divine mandate into the mix, asserting that:

the European (or white race of men) has never been a polygamist before. It is contrary to his nature and instincts. Created, manifestly, for a higher destiny — an instinctive abhorrence of the brutality of a promiscuous intercourse is impressed upon the males and especially the females of the race. ${ }^{125}$

While these views seem cartoonish a century and a half later, we need only look to actual cartoons of the day to see how common they were.

Over and over, antipolygamy cartoons deride plural marriage as a disorderly or backward domestic arrangement, implicitly analogizing household disorder to government disorder. Chaotic domestic scenes depict brawling wives and screaming children while a sidelined husband fails to exercise proper authority over his wives and children by virtue of being outnumbered. ${ }^{126}$ Racial disorderliness frequently makes an appearance in these scenes through one Black child among many White ones, like "The Carrion Crow" already described. Another popular image is one White Mormon man accompanied by many wives of different races and nationalities, making the numerosity and miscegenation jokes in the same

${ }^{123}$ WASHINGTON, supra note 114 , at 36. Cartwright "discovered” slave diseases such as "drapetomania” (the pathological desire to flee slavery) and "dysaethesia aethiopica” ("called by overseers 'rascality,"” and "so great a hebetude of intellectual faculties, as to be like a person half asleep” which, according to Cartwright, afflicted "nearly all” free Blacks "that have not got some white person to direct and to take care of them.”). Id.

124 Talbot, supra note 4, at 336 (quoting Samuel A. Cartwright, in Hereditary Descent, supra note 116, at 214).

${ }^{125}$ Id. (quoting Forshey, in Hereditary Descent, supra note 113, at 211).

${ }^{126}$ See, e.g., The Elder's Happy Home, CHIC, Apr. 19, 1881, reprinted in BUNKER \& BitTon, supra note 78 , at 89. 
breath. ${ }^{127}$ Implicitly, these scenes assert that if Mormons cannot govern their households, they cannot properly govern their territory. Some cartoons feature Uncle Sam as a father figure, either disciplining the unruly children (who might signify territories or unpopular groups), or lounging in an armchair when he should be disciplining "problems" like Mormons and Indians for defying federal authority. ${ }^{128}$

Effeminacy, frightening numerous women and children, and racial and national diversity of those wives and children seem like code for the danger of racial degeneration and collective disorder through polygamy. For example, an 1870 cartoon titled "A Mormon Family out for a Walk" features one wizened, weak man leading four or five wives of various races and nationalities. ${ }^{129}$

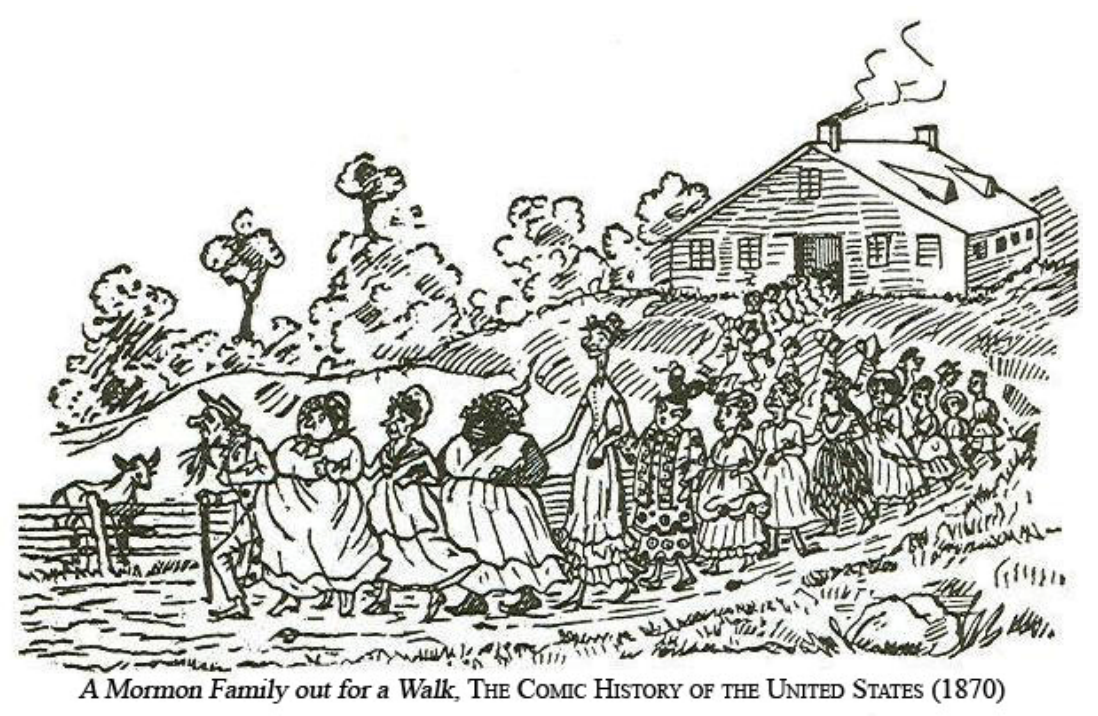

Here, one Black wife (portrayed as a mammy) is trailed by an ugly one, the latter figure perhaps joking that in polygamy even a plain Jane can get married. A Japanese figure could be wife or child. Scores of children follow behind. Thirty years later, as Congress held hearings to determine whether

${ }^{127}$ See, e.g., A Mormon Family Out for a Walk, in THE COMIC HISTORY OF THE UnITED STATES (1870), reprinted in BunKER \& BitTON, supra note 78, at 130.

128 See, e.g., The Three Troublesome Children, THE WASP, Dec. 16, 1881, reprinted in BUNKER \& BITTON, supra note 78, at 79; GORDON, supra note 16, at 205.

${ }^{129}$ A Mormon Family Out for a Walk, supra note 127. 
Mormons still practiced polygamy, the joke still had traction. A 1904 cartoon titled "Mormon Elder-berry-Out with His Six Year-Olds, Who Take after Their Mothers," published in Life Magazine, ridicules Mormon fecundity as well as racial and national diversity. ${ }^{130}$

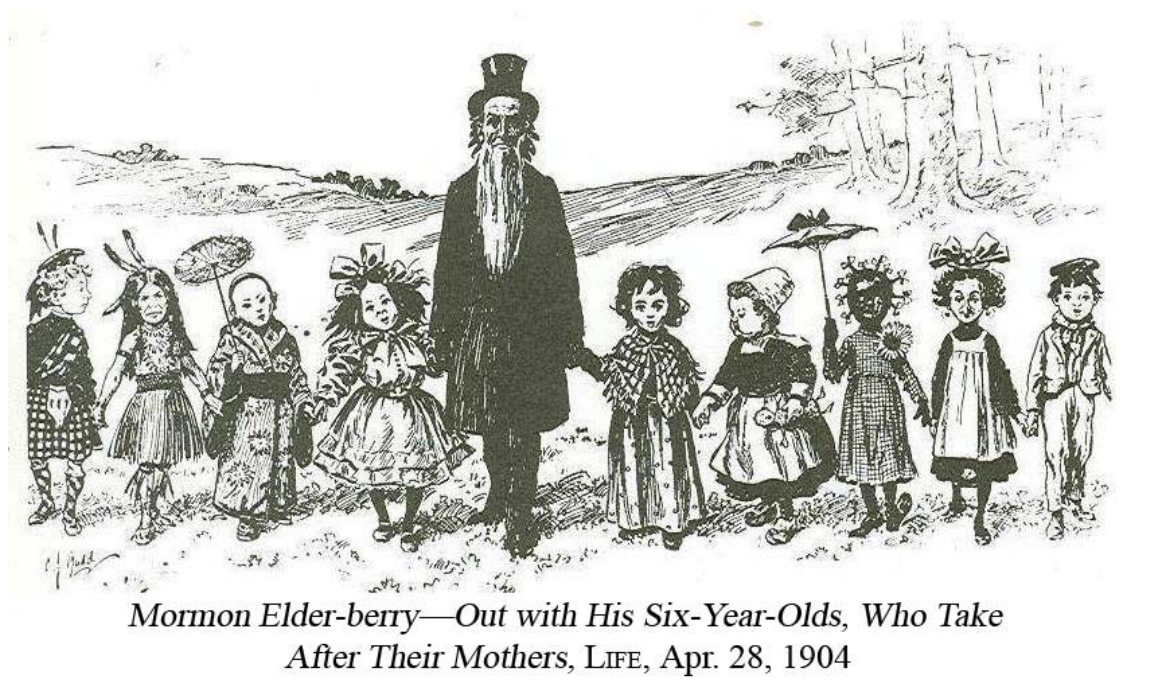

In this image the polygamist father's name, "Elder-berry" may be a play on Mormons' habit of calling even young men "Elder," and perhaps also a racial joke for those who knew the scientific name of elderberry, or Black Elder, was "Sambucus Nigra." "131 The main joke seems to stem from what Barthelow called the "preponderance of female births" (all but one or two of the children appear to be female) and ethnic diversity as reflected by the Scottish, Native American, Japanese, Dutch, and African American children of this White man.

Back in the 1880s, Mormons determinedly continued to practice polygamy, despite multiple federal statutes and a line of cases upholding the federal government's efforts to force them to stop. ${ }^{132}$ Two cartoons feature

${ }^{130}$ Mormon Elder-berry-Out with His Six Year-Olds, Who Take after Their Mothers, LifE, Apr. 28, 1904, reprinted in BunKER \& BITTON, supra note 78, at 81.

${ }^{131}$ Few readers might have known of elderberry's medicinal and ornamental uses, as well as the fact that it is poisonous to mammals and is often classified as a weed. See U.S.D.A. Natural Resources Conservation Service, Common Elderberry Plant GuIDE (2006), available at http://plants.usda.gov/plantguide/pdf/cs_sanic4.pdf.

\footnotetext{
132 GoRDON, supra note 16 , at 87.
} 
domestic scenes decrying polygamy's political and domestic disorder, as well as the federal government's inability to end the practice. "The Elder's Happy Home," published in April of 1881, presents the familiar scene of a sidelined patriarch overwhelmed by his many wives and children: ${ }^{133}$

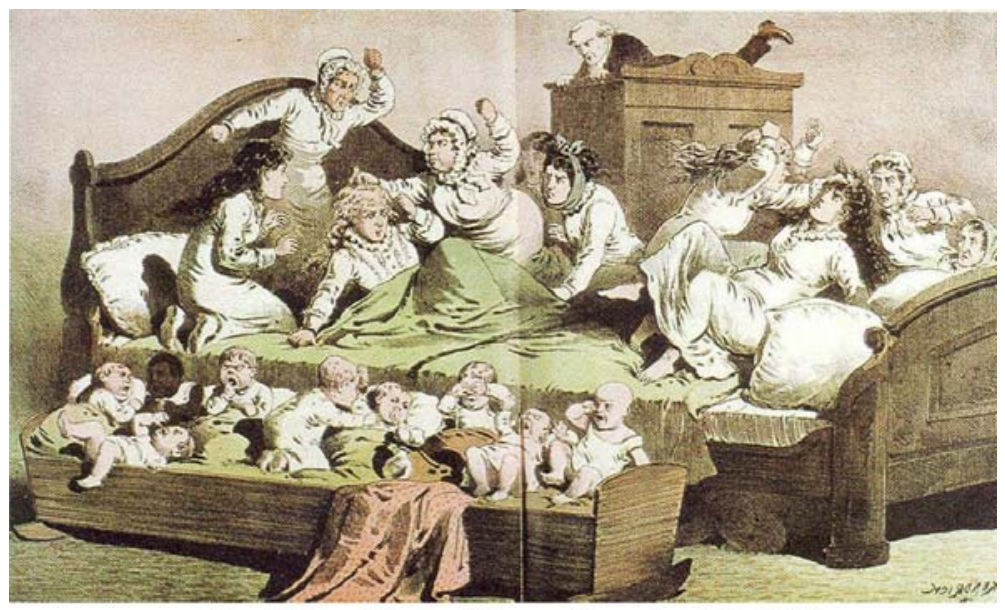

The Elders' Happy Home, CHг, Apr. 19, 1881

Unlike Mormon Elder-berry, this Mormon elder cannot govern his huge family, and lies prone on the armoire to the right. While Elder-berry's six-year-olds obediently hold hands, these numerous wives and children scream and fight. Note the one Black child in the cradle. Like "The Carrion Crow" in the cartoon discussed above, ${ }^{134}$ this lone Black child could reference miscegenation (though none of the wives appear Black), the "Blackness" of the entire scene, or a future in which purportedly White domestic ordering gets displaced by chaotic scenes like this one.

Another 1881 cartoon, titled "The Three Troublesome Children," similarly associates political and domestic disorder with Mormon polygamy, adding an explicitly political dimension by referencing federal treatment of Chinese and Native Americans. ${ }^{135}$

\footnotetext{
${ }^{133}$ The Elder's Happy Home, supra note 126.

${ }^{134}$ See supra note 78 and accompanying text.

135 The Three Troublesome Children, supra note 128.
} 


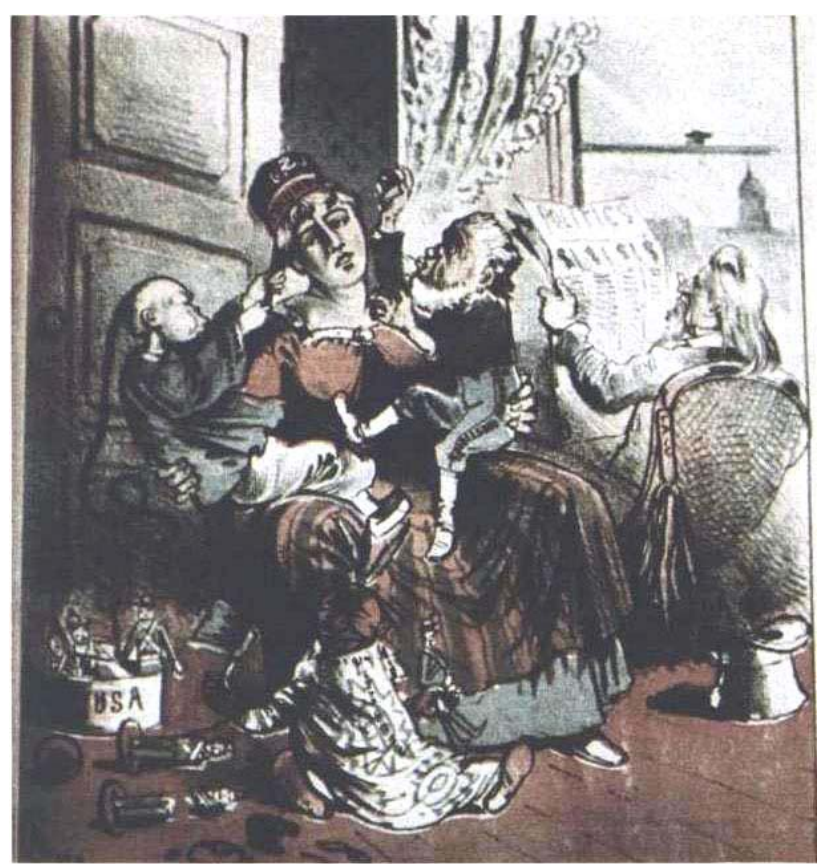

The Three Troublesome Children, THE WASP, Dec. 16, 1881

Like Uncle Sam's “troublesome bedfellows,” discussed earlier, ${ }^{136}$ this cartoon deploys a domestic scene to argue for limiting pluralism in the growing nation. But where Uncle Sam was booting Mormon and Chinese "problems" out of bed in "Uncle Sam's Troublesome Bedfellows,", he is inactive. He languidly reads a newspaper labeled "Politics," dollar signs in the place of headlines suggesting concern with commerce rather than the more immediate matters demanding attention in the cartoon's foreground. There, three "troublesome children" harass a beleaguered Columbia. On one knee a Chinese child pulls Columbia's hair like the Native American poking a finger in Uncle Sam's ear in the “Troublesome Bedfellows" cartoon. ${ }^{138}$ On the other knee a simian polygamist batters her with a pipe, and at her feet a Native American child sits, clubbing lead U.S. soldiers with a tomahawk. The blanket draped across Uncle Sam's wicker chair, labeled "Law," suggests the (unused) remedy for this abuse: more statutes and more prosecutions.

\footnotetext{
${ }^{136}$ See supra note 93 and accompanying text.

${ }^{137}$ Id.

${ }^{138} \mathrm{Id}$.
} 
Indeed, Congress passed the third antipolygamy statute, the Edmunds Act, on March 22, 1882, ${ }^{139}$ just three months after the Wasp published "The Three Troublesome Children." that Congress also passed the anti-Chinese Fifteen Passenger Act in 1882. Reading the two statutes in light of cartoons like "The Three Troublesome Children" situates the antipolygamy statute squarely within a larger press to define citizenship in racial terms. ${ }^{140}$

Another cartoon, published in between the third and fourth antipolygamy statutes, enthusiastically supported the use of federal force to move Mormons back toward Whiteness. In 1885, the Judge published a cartoon captioned "Hit 'em Again." 141 It features a Crusader whose tunic seems labeled "Edmunds," seemingly representing the Vermont Senator George Edmunds for whom the 1882 Edmunds Bill is named. The cartoon emphasizes the knight as personification of the Federal Government with his armored forearms, resembling columns on an American government building, in sharp contrast to the feudal towers of the "Mormon Castle" in the background. Edmunds wields a sword labeled "Edmunds Bill" over a cowering Turk, who clasps a primitive club labeled "polygamy." The contest's outcome is made clear by the Turk's cowering posture, coupled with the viewer's knowledge that the polygamist's blunt, if menacing, club is no match for Edmund's sharp sword (just as his flimsy headscarf is no match for Edmunds' armor helmet).

139 Edmunds Act, ch. 47, 22 Stat. 30 (1882) (codified at 48 U.S.C. § 1461) (repealed 1983).

${ }^{140}$ While post-Civil War legislation granted citizenship to "aliens of African nativity and persons of African descent," it continued to bar even native-born Asian Americans from citizenship until 1898. ANGELO N. ANCHETA, RACE, RigHTS AND THE ASIANAMERICAN EXPERIENCE 23-24 (2d ed. 2006). Not until the 1940s did Asian immigrants obtain citizenship rights. Id. The Supreme Court upheld race-based exclusions, asserting that if "the government of the United States, through its legislative department, considers the presence of foreigners of a different race in this country, who will not assimilate with us, to be dangerous to its peace and security, their exclusion is not to be stayed." Chae Chan Ping v. United States, 130 U.S. 581, 606 (1881). For a brief description of various aspects of citizenship, see Volpp, supra note 95, at 71-72.

${ }^{141}$ Hit 'em Again, The Judge, 1885, reprinted in Bunker \& BitTon, supra note 78, at 118; GORDON, supra note 16, at 184 . 


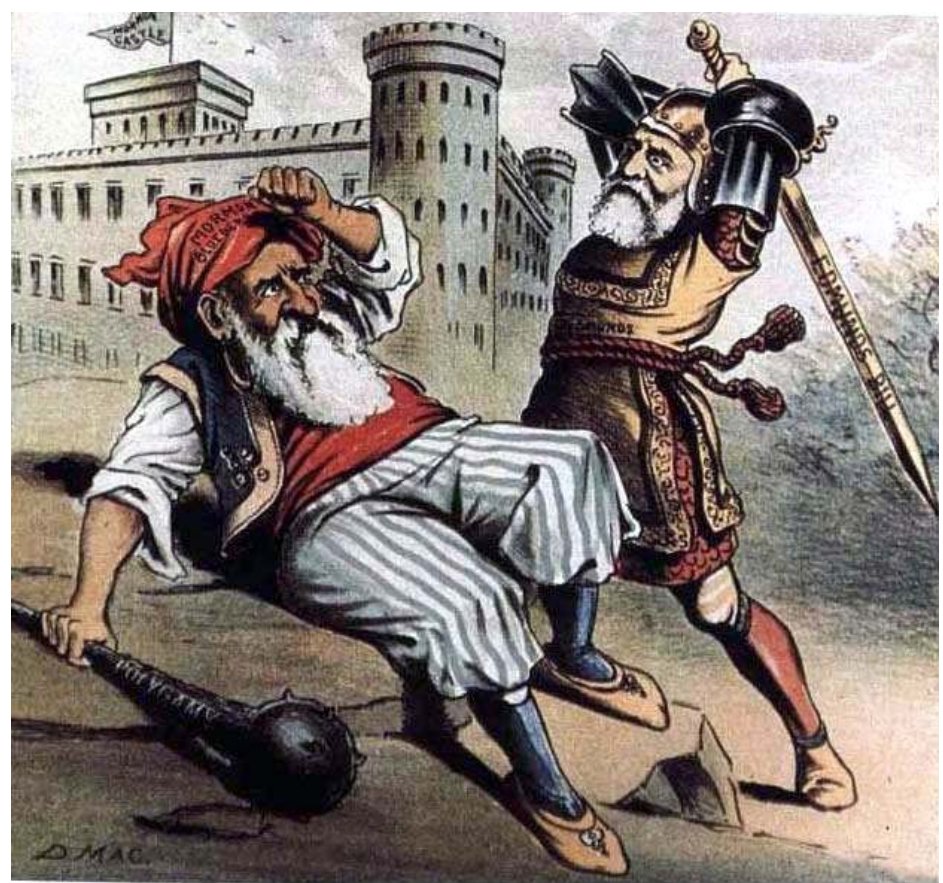

Hit 'em Again, THe Judge, 1885

Nineteenth century viewers could hardly be surprised to see the Mormon Question played out as a battle, given the Mormon War. The battle lasted a full fifty years in large part because, unlike the cringing Turk, the Mormons fought back, often using the very same tools aimed against them.

\section{Mormon Response: Polygamy Improves the Race}

Consistent with Mormons' millennial beliefs, they contended plural marriage would elevate Mormons to something like divine status by producing a "special race, possessing the complexions of angels," 142 and ushering in the Millennium. While they rejected the theory of biological evolution, they appropriated Darwinian imagery to argue what Territorial Representative in Congress, George Q. Cannon, called "the physiological side" of polygamy. ${ }^{143}$ Just as Cartwright and Forshey marshaled "scientific"

\footnotetext{
${ }^{142}$ Hardy \& Erickson, supra note 115, at 58 (citing Territorial Representative George Q. Cannon).

${ }^{143}$ Id. at 56, 57.
} 
arguments attesting to Mormon physiological weakness, ${ }^{144}$ a Mormon named George A. Smith lauded academic research predicting that the Mormon practices would "in about seventy years ... produce a race of men who would be able to walk the rest of the human race under foot." 145 Consistent with this aggressive claim, Mormon leader Joseph F. Smith declared "Our business is to reclaim this earth. We have set out to regenerate the human family." 146 In some respects, they were more open than other White Americans to embracing whole human family. Rather than invariably distancing themselves from the Orientalist imagery described above, Mormons sometimes embraced the association with foreignness, Catholicism, and non-democratic governments. One article in the Mormon newspaper Millennial Star predicted that before the turn of the twentieth century, Mormon polygamists would be sent overseas as "rulers and ambassadors" and "receive as much adulation, world-wide applause, and national respect . . . as the Grandest Sultan, the Holiest Pope, or the most powerful Emperor could desire." ${ }^{147}$ Indeed, rather than concede the barbarity of polygamy, Mormons contended that plural marriage was more civilized than monogamy. Mormon physician Romania Pratt echoed these claims, deployed rhetoric associating monogamy with darkness and barbarism:

With this principle universal, but limited and governed by laws of marriage inhibiting sensuality and selfishness ... the solution to the growing social evil would be found. ... Were this the order of the world, abortions, feticides, infanticides, seductions, rapes and divorces would be relics of the barbarous age, while intelligence, light, peace and good will and love would be the motor forces of the world-in short the Millennium would have come. $^{148}$

These political and theological assertions reveal both why so many Americans feared and despised the Mormons, and also the ideological

\footnotetext{
${ }^{144}$ See supra Part III.C.

${ }^{145}$ Hardy \& Erickson, supra note 115, at 57.

${ }^{146}$ Id. at 58.

${ }^{147}$ Id. at 59 (quoting Charles W. Penrose, Polygamy and the Visit of the Sultan,

${ }^{148}$ Hardy \& Erickson, supra note 115, at 61 (quoting Romania Bunnell Pratt, Extract from Dr. R.B. Pratt's Lecture, WoMAN's EXPONENT, June 15, 1881, at 16).
} MillenNial Star, Aug. 3, 1867, at 492-93). 
structures that enabled Mormons to withstand intense Federal pressure for nearly half a century. But Americans who bristled at the very idea of Mormon polygamy did so for different reasons.

\section{E. Plurality of Opinion about Mormon Polygamy}

The discourse examined thus far shows how many White and mostly male Americans used polygamy to shore up white supremacy. While many African American and feminist commentators shared the mainstream views of polygamy as barbaric and dangerous, ${ }^{149}$ they focused on different aspects of similar arguments. Most notably, African Americans did not voice concerns about race degeneration, instead using antipolygamy arguments before the war to buttress anti-slavery arguments, and overall to enhance African American's citizenship claims by associating polygamy with foreign-ness. Feminists, in contrast, disagreed over whether to support Utah granting women the vote in 1870 , and also whether monogamy, championed by antipolygamists, was itself harmful to women.

African Americans used antipolygamy sentiment to bolster antislavery arguments by pointing out that defenders of both "peculiar institutions" justified them as biblically authorized or protected under principles of local control. An 1854 article, for example, ridiculed biblical defenses of slavery by pointing out that "polygamy can in the same manner, be justified by 'biblical texts and passages." "150 Another piece published a few weeks later derided local control arguments as "squatter sovereignty":

"Squatter Sovereignty," the nest in which Slavery was to be warmed into life, is the nest in which this vile system of

${ }^{149}$ An 1899 column in the Afro-American warned of the harms that polygamy posed for the nation itself:

Polygamy in Utah, though outlawed, is still practiced in secret. It has warred against the marriage relation throughout the land. It is impossible to have such an awful sewer of inequity sending up its miasma, which is wafted by the winds north, south, east and west, without the whole land being affected by it.

Afro-Am., Sept. 23, 1899, at 4. Like mainstream periodicals, African Americans found humor in polygamy, as shown by a quip printed in 1912 in The Chicago Defender, "Teacher- 'The right to have more than one wife is called polygamy. What is it when only one wife is allowed a man?' Willie-'Monotony, ma'am.'” As It seems to Willy, THE CHICAGo DEFENDER, June 1, 1912, at 5 (copy on file with author).

150 A Reverend Defender of Slavery, in FrEDERICK Douglass PAPERS (1854) (copy on file with author). 
Polygamy has been hatched . . . In virtue of it, infanticide and sutteeism may spring up and flourish in our Western Territories, whenever there shall be enough immigrants from Asia to constitute Territorial Governments - and this Federal Government must look on in silence, its wings outspread over all things hateful and devilish. ${ }^{151}$

The danger of powerful individual states emerges again in an 1854 article describing Brigham Young as "a law unto himself," who "has squatted upon the territory of the United States," and linking Young's "peculiar institution of polygamy” with the Mormons' separatist theocracy:

Another peculiar institution of Utah is the amalgamation of Church and State, both of which Brigham Young is supreme head. In short, the power and influence of Young is as unlimited as the number of his wives or of his progeny. ${ }^{152}$

Some African American commentators, like the mainstream, associated polygamy with Asia and Africa. In 1898, for example, the Rev. Dr. Talmage exhorted readers of the Afro-American to cultivate loving and orderly families, warning that "[s]ocialism and polygamy, and the most damnable of all things, free-lovism, have been trying to turn this earth into a Turkish harem." ${ }^{153}$ Similarly, the Christian Recorder, newspaper of the African Methodist Episcopal Church, published pieces associating polygamy with Islam and decrying African polygamy as "the chief obstacle to the spread of Christianity." "154

Other African American commentators used polygamy to argue for federal intervention in other, more pressing problems, like lynching. An 1899 editorial in the African American newspaper Cleveland Gazette exemplifies this view. An "eminent and race-loving Afro-American

151 Squatter Sovereignty and Polygamy, NATIONAL ERA, Mar. 24, 1854, reprinted in FREDERICK DOUgLASS PAPERS, supra note 150.

152 Let the People Rule, THE NORTH STAR, Dec. 22, 1854, reprinted in FREDERICK Douglass PAPERs supra note 150. Douglass published the North Star beginning in 1841. See American Treasures in the Library of Congress, http://www.loc.gov/exhibits/treasures/trr085.html (last visited Mar. 1, 2010). 5,1898 , at 4 .

${ }^{153}$ Rev. Dr. Talmage, The Eminent Divine’s Sunday Discourse, Afro-AM., Nov.

154 Christian Recorder, July 23, 1874. See also Rev. A.M. Stewart, Letters XXXII, Mormons, CHRISTIAN RECORDER, March 20, 1869 (copy on file with author). 
gentleman" roundly condemned Mormon polygamy, then urged the government remedy the injustices of lynching:

As bad as is the sin of polygamy, it does not seek the lives of human beings. It indulges in no vengeful feeling of resentment, mutilating, butchering, torturing and burning living mortals only to appease a brutal nature. But lynch law does all this and more. . .. The government dares to challenge the right of polygamy, but tremblingly and pitifully it quails in the presence of a gigantic crime which every day gathers strength and flaunts its murderous blood-stained hands in the face of Christendom. ${ }^{155}$

Along the same lines, African American activist and novelist Frances Harper had a character in her 1892 novel Iola Leroy sharply observe that post-Civil War federalism created an "aristocracy of race wide enough to include the South with its treason and Utah with its abominations, but too narrow to include the bravest colored man" who fought for the Union Army. ${ }^{156}$ In short, African Americans seem to have responded strategically to the antipolygamy campaign. They marshaled popular antipolygamy arguments toward their own ends of abolishing slavery and, later, defending Black citizenship claims. While some African Americans shared the common association of polygamy with Asia and Africa, the few materials available appear aimed at strengthening African American citizenship claims, perhaps by dissociating from other unpopular groups like Asians.

Nineteenth century feminists also engaged in polygamy debates to serve their own ends. However, while African American commentators uniformly condemned polygamy, feminist responses were slightly more mixed. Female suffrage and changing regulation of marriage were central to feminist attitudes toward polygamy.

A good number of feminists initially praised Utah for granting women the vote in 1870, and argued that enfranchising Utah women would eliminate Mormon polygamy, predicting that Utah women would vote it out of existence. "157 One major group, the National Women's Suffrage Association ("NWSA"), went further, departing sharply from mainstream

155 Polygamy or Lynching?, Cleveland GazetTe, Nov. 18, 1899, at 2, available at http://dbs.ohiohistory.org/africanam/det.cfm?ID=19214.

156 Bentley, supra note 92, at 357 (quoting FranCES E.W. HARPER, IOLA LEROY, OR SHAdOWs UPLIFTEd 233 (Oxford University Press 1988) (1892)).

1572 The History of Woman Suffrage 420 (Elizabeth Cady Stanton, Susan B. Anthony, \& Matilda Joslyn Gage eds., Source Book Press 1970) (1887). 
condemnation of polygamy by making common cause with polygamist wives. ${ }^{158}$ The American Women's Suffrage Association (“AWSA”), in contrast, refused to work with polygamous wives. ${ }^{159}$

The NWSA's embrace of polygamous wives allowed those feminists to use the defects of polygamy to point out similar defects in monogamy, akin to the way some African Americans used polygamy as a club to combat slavery. Matilda Jocelyn Gage, abolitionist and NWSA leader, argued that both Mormon polygamy and Christian monogamy reduced women to slaves, as did every religion:

Polygamy is but one development of the doctrine of woman's created inferiority, the constant tendency of which is to make her a mere slave under every form of religion extant. ${ }^{160}$

In 1871, shortly after Utah enfranchised women, Susan B. Anthony and Elizabeth Cady Stanton visited Utah and spoke to Mormon women at the Tabernacle. ${ }^{161}$ Stanton's description of this discussion reveals her view that Mormon women shared common burdens with other women:

I gave a brief history of the marriage institution in all times and countries, of the matriarchate, when the mother was the head of the family and owned the property and children; of the patriarchate, when man reigned supreme and women were enslaved; of polyandry, polygamy, monogamy, and prostitution. We had a full and free discussion of every phase of the question, and we all agreed that we were still far from having reached the ideal position for women in marriage however satisfied man might be with his various experiments. Though the Mormon women, like all others, stoutly defend their own religion, yet they [are] no more satisfied than any other sect. ${ }^{162}$

${ }^{158}$ Carol Weisbrod \& Pamela Sheingorn, Reynolds v. Unites States: NineteenthCentury Forms of Marriage and the Status of Women, 10 ConN. L. REV. 828, 840 (1978).

${ }^{159}$ Id.

${ }^{160}$ Matilda Joslyn Gage, Woman, Church, and State 424 (Arno Press Inc. 1972) (1900).

${ }^{161}$ Id. at 25-26.

162 Elizabeth Cady Stanton, Eighty Years And More 284 (Source Book Press 1970) (1898). 
She went still further afield of mainstream ridicule of Mormonism by acknowledging their good will and Biblical authority for polygamy, though ultimately asserting that "religions are human inventions":

I stood among these simple people, so earnest in making their experiment in religion and social life, and remembered all the persecutions they had suffered . . . . Their faith finds abundant authority in the Bible, in the examples of God's chosen people. . . . When women understand that governments and religions are human inventions ... they will no longer be oppressed by the injunctions that come to them with the divine authority of "Thus saith the Lord."163

This posture of solidarity with women qua women, and skeptical posture toward all religions, led the NWSA, unlike the AWSA, to work alongside Mormon women. In 1879, the NWSA invited two Mormon women, Emmeline B. Wells and Zina Young Williams, to the National Women's Suffrage Convention in Washington, DC. ${ }^{164}$ Wells was currently in a polygamous marriage. Young was Brigham Young's daughter and a widowed plural wife. ${ }^{165}$

The AWSA, in contrast, refused to associate with Mormon women. This allegiance to convention also found expression in the AWSA's view of polygamy as both different from and inferior to Christian monogamy. An article in the AWSA magazine the Women's Journal melded monogamy and Christianity by analogizing Christ appointing Peter as the rock which he based his church to monogamy's role for women's equality, ${ }^{166}$ asserting that " $[\mathrm{m}]$ onogamy is the rock upon which the church of Woman's Equality is founded." ${ }^{167}$ But although AWSA leaders like the married couple Lucy Stone and Henry Blackwell condemned Mormon polygamy, they sharply criticized marital conventions themselves. When they married in 1855,

163 Id.

164 JoAn SMYth IVERSEN, THE ANTIPOLYGAMY CONTROVERSY IN U.S. WOMEN's Movements, 1880-1925: A DEBATE ON THE AMERICAN Home 29 (Angela Zophy ed., 1997).

165 Id.

166128 Matthew 16:13-18 (King James) (“upon this rock I base my church”).

167 Carol Weisbrod \& Pamela Sheingorn, Reynolds v. Unites States: NineteenthCentury Forms of Marriage and the Status of Women, 10 ConN. L. REV. 828, 840 (1978) (quoting Woman's Rights Versus Polygamy, WomaN’s J., June 1879, at 196). 
Stone retained her maiden name, ${ }^{168}$ and they altered their wedding vows to defy legal rules that subordinated wives:

While acknowledging our mutual affection by publicity assuming the relationship of husband and wife . . . we deem it a duty to declare that this act on our part implies no sanction of, nor promise of voluntary obedience to such of the present laws of marriage as refuse to recognize the wife as an independent, rational being, while they confer upon the husband an injurious and unnatural superiority. ${ }^{169}$

The NWSA used this resistance to off-the-rack monogamy to fight back when the AWSA publicly condemned the NWSA for associating with Mormon women. ${ }^{170}$ The NWSA's Gage chided Stone and Blackwell for criticizing polygamy when they themselves tried to alter the terms of conventional marriage, observing that "[i]t ill becomes those living in the Glass House ... to throw stones at Mormon women."171

But even the NWSA had its limits. By 1882, when Utah women's votes over a decade had not eradicated polygamy, the NWSA instructed polygamous women not to attend the NWSA national convention and banned them from speaking at the New York State Women's Suffrage Convention. ${ }^{172}$ Anthony worried about the NWSA appearing to endorse

168 See Eleanor Flexner, Century of Struggle 64 (1975).

169 1The History of Woman Suffrage 260-61 (Elizabeth Cady Stanton, Susan B. Anthony, \& Matilda Joslyn Gage eds., Source Book Press 1970) (1881).

${ }^{170}$ IVERSEN, supra note 164, at 31.

${ }^{171}$ Id. (quoting Matilda J. Gage, The Brand of the Slave, 3 NAT'L CitizEN \& Ballot Box, Dec., 1878, at 2). Nineteenth century feminists also feuded over how to respond to the Fourteenth and Fifteenth Amendments. The Fourteenth Amendment was ratified in 1869, it defined "citizens" and "voters" as "male," writing the term "male" into the constitution for the first time. IVERSEN, supra note 164, at 23. NWSA leaders vigorously opposed granting Black men the vote before all women, a view that scholars have viewed as radical in comparison to the centrist or even conservative AWSA. Id. NWSA leaders Susan B. Anthony and Elizabeth Cady Stanton worked with African Americans and other White women to form the Equal Rights Association in 1866 to seek the vote for Black men and all women, and the NWSA aimed to reform marriage and gender more broadly in society. Id. The AWSA, in contrast, pursued the more narrow goal of female suffrage. Id. However, angry after the Fifteenth Amendment enfranchised Black men, but not any women, Anthony acidly noted that educated white women were more entitled to vote than "the most ignorant foreigner or slave from the plantations of the South.” 2 THE HistORY OF WOMAN SUfFrage, supra note 157 , at 88 .

${ }^{172}$ IVERSEN, supra note 164, at 165. 
polygamy, and when she, Stanton, and Gage wrote the Utah chapter of The History of Woman Suffrage, they managed to chronicle the Mormon women's struggle against disenfranchisement without even mentioning polygamy. ${ }^{173}$

Despite this range of nineteenth century Americans' views of polygamy, the most influential decision makers grounded federal antipolygamy statutes and case law on the political and race treason of Mormons in establishing a separatist theocracy. Having uncovered the racial underpinnings of American polygamy law, the remainder of the Article offers two theoretical frameworks to understand it.

\section{TWO FRAMEWORKS FOR RETHINKING POLYGAMY LAW}

Two theoretical frameworks help organize the cacophony of images and words of the polygamy debates. This Part first applies Said's concept of Orientalism ${ }^{174}$ to shed light on the role of racial status in the cartoons' depictions of polygamous Mormons as racial and ethnic Others. Second, it taps Sir Henry Maine's famous observation in 1864-in between the first and second federal statute to ban polygamy_— that "the movement of the progressive societies has hitherto been a movement from Status to Contract." 175 Together, Orientalism and status/contract tensions help explain the complex role of white supremacy in polygamy law.

\section{A. Orientalism}

Said's approach shows how, by equating Mormons with Chinese Americans, "the same network of interests is brought to bear as in other occasions when 'the Orient' is in question."176 Though crafted to analyze the "us/them" frameworks in colonialism, Orientalism, used cautiously, offers a sophisticated way to interpret racist antipolygamy discourse in

${ }^{173}$ See 4 The History of Woman Suffrage 936-56 (Susan B. Anthony \& Ida Husted Harper eds., Source Book Press 1970) (1902) (mentioning antipolygamy legislation such as the Edmund-Tucker Act, but excluding any discussion of polygamy). NWSA member Belva Lockwood continued to support Utah women, condemning antipolygamy legislation at the 1883 NWSA Convention on religious freedom grounds. Belva A. Lockwood, The Disfranchisement of the Women of Utah, WoMEN's ExPONENT, June 15, 1883, at 12 .

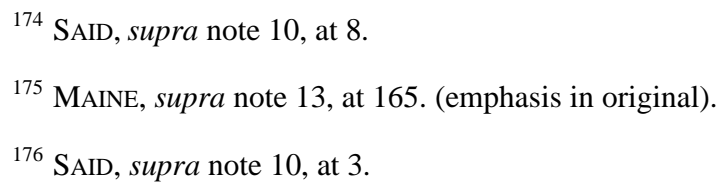


nineteenth century America. ${ }^{177}$ It integrates the political and racial treason charges within a single rubric, bringing antipolygamy rhetoric under the mantle of colonialism and white supremacy for its depiction of White Mormons as racial throwbacks with supposedly "Oriental" characteristics like primitivism, sensuality, and submissiveness to despotism. ${ }^{178}$ Using the insights of Orientalism, one can use its premise that racial and national groups are fundamentally different, and moreover that these essential differences justify treating some groups ("them") as essentially inferior than others ("us"). "We" were White, Protestant, native born, and descended from England and Northern Europe (but not Ireland). "They,” in contrast, were Asian, African American, Native American, Catholic, and Irish. Over and over, antipolygamy rhetoric portrayed Mormons in reference to what Said calls these "essential aspects of the Orient": despotism and sensuality. ${ }^{179}$ In short, Orientalism offers a shorthand for describing a situation in which the Other gets racialized, and the racialized Other gets put in its place.

In Reynolds $v$. United States, the Supreme Court did just that by equating polygamy with "Asiatic and African peoples," then quoting political scientist Francis Lieber's link between polygamy and stationary despotism. ${ }^{180}$ Lieber was among the country's leading academics, having written influential political science texts, and also a former slaveholder. ${ }^{181}$ In 1855, two decades before Reynolds, Lieber wrote an article in Putnam's Monthly using the first person singular, inviting his readers to frame the question of Mormon citizenship in "us/them” terms:

Mormonism is one of those subjects in history which ... make[s] the beholder bend down with averted face and exclaim- "I, too belong to this race!” The mischief which large crimes leave upon

177 Colonialism differs tremendously from Federal/territorial relations, not least because white Mormons themselves colonized the American West even as the Federal government exercised extraordinary authority over the Mormons. Talbot, supra note 4, at 359 n.24. Moreover, Orientalism takes a variety of forms. Ruskola, supra note 11, at 195.

178 SAID, supra note 10, at 203.

${ }^{179}$ Id. See also Bentley, supra note 92, at 344-45, 356, 358.

18098 U.S. 145, 164, 165 (1879).

${ }^{181}$ CotT, supra note 17 , at 114-15. Lieber wrote the leading political science textbook, Manual of Political Ethics, which also became "the standard work cited in legal treatises and lawyer's briefs on the proper respect for, and restriction of, women in politics and law." GoRDON, supra note 16, at 140. 
the whole race, is as great in its downward direction, as the instances of noble individuals and nations are in their elevating effects. ${ }^{182}$

Lest readers think Lieber meant "the human race" when he exclaimed, "I, too belong to this race," he clarified that he meant the "race" of European, civilized White men:

Wedlock, or monogamic marriage . . . is one of the elementary distinctions-historical and actual-between European and Asiatic humanity. . . . It is one of the pre-existing conditions of our existence as civilized white men, as much so as our being moral entities is a pre-existing condition of the idea of law. . . . Strike it out, and you destroy our very being; and when we say our, we mean our race- - a race which has its great and broad destiny, a solemn aim in the great career of civilization, with which no one of us has any right to trifle. ${ }^{183}$

While Lieber admitted that "[t]here have been a few exceptions to the pervading monogamic spirit of our western Caucasian race," ${ }^{184}$ his association of Whiteness with civilization and monogamy was all too clear. The influence of this association increased when, a generation after Lieber published this article, the Supreme Court in Reynolds transformed his view into legal precedent by linking polygamy to purportedly backward "Asiatic and African peoples" and to a primitive form of government, "stationary despotism." 185

The Supreme Court's tendency to associate polygamists with the Orient, using us/them language, extended to other polygamy cases. In the Late Corporation case, the Court upheld the Edmunds-Tucker Act that directed the Attorney General to seize the Church's property and begin winding down its affairs. The Court referred to English people as "our own ancestors" and emphasized the Asian-ness of polygamy by using two Indian examples of practices that fall outside of the free exercise of religion:

${ }^{182}$ Francis Lieber, The Mormons: Shall Utah be Admitted into the Union?, 5 PutNAM’s MonTHLY 225, 233-34 (1855).

${ }^{183}$ Id. (emphasis in original).

${ }^{184}$ Id.

${ }^{185}$ Reynolds, 98 U.S. at 164, 165-66. 
No doubt the Thugs of India imagined that their belief in the right of assassination was a religious belief; but their thinking did not make it so. The practice of suttee by Hindu widows may have sprung from a supposed religious conviction. The offering of human sacrifices by our own ancestors in Britain was no doubt sanctioned by an equally conscientious impulse. But no one, on that account, would hesitate to brand these practices, now, as crimes against society, and obnoxious to condemnation and punishment by the civil authority. ${ }^{186}$

The "Thugs of India," like Mormon polygamists, captured the nineteenth century public imagination in America and England. Thugs were reputed to be devotees of Kali, the Hindu goddess of destruction, who roamed the countryside robbing and murdering travelers, then offered spoils of the crime as sacrifices to the goddess. ${ }^{187}$ The Court's second example, Hindu widows immolating themselves, similarly drew on associations between Mormon polygamy and harm to women, as well as foreign, particularly Asian, manifestations of Otherness.

\section{B. Henry Maine's Claim that Progressive Societies Move from Status to Contract}

To situate the polygamy debates within Henry Maine's observation that "the movement of the progressive societies has hitherto been a movement from Status to Contract," 188 it helps to know what he meant by "progressive," "status," and “contract." Maine meant "progressive” in a literal sense, meaning movement, contrasting it with "stationary," barbaric societies in China and India. ${ }^{189}$ By "status" he meant "Patriarchal Theory," positing it as the genesis of all known societies, in which fathers exercised unqualified dominion over their wives, children, and slaves. ${ }^{190}$ Contract, in

${ }^{186}$ Late Corp. of Church of Jesus Christ v. United States, 136 U.S. 1, 49-50 (1890) (emphasis added). Indeed, Lieber used the examples of suttee and the Thugs of India in his Putnam's article to justify the distinction between permitted beliefs and forbidden actions. Lieber, supra note 191, at 232.

${ }^{187}$ Philip Meadows Taylor, Confessions of a Thug (Oxford Univ. Press 1986) (1839); Martine Van Woerkens, The Strangled Traveler: Colonial IMAGinings AND THE THUGS OF INDIA 1-9 (Catherine Tihanyi trans., 2002).

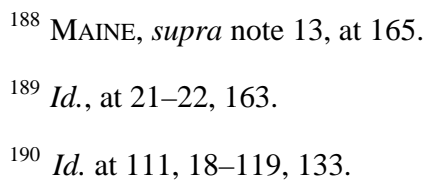


his view, replaced the rule of the family with the growth of "individual obligation" in the West. He recognized however that, even in Western Europe in the 1860s, women remained stuck in an "archaic jurisprudence .. . retaining [them] in the bondage of the Family for life." ${ }^{191}$ Today, progressives would wince at Maine's use of "progressive" to denote Western Europe, in contrast to barbaric and primitive "Hindoos" of India, ${ }^{192}$ since twenty-first century speakers use the term "progressive" to reflect respect for individual rights and equality among citizens, regardless of religion, ethnicity or sex. ${ }^{193}$ Yet classical liberalism, the philosophical home of Henry Maine's ideas about freedom of contract, can both support and undermine equality.

Contractualism's progressive pedigree includes reforms like the Married Women's Property Acts, and the gradual replacement of slavery with wage labor, which capture "the evolution of individualism, the gradual recognition of the legal personhood of wives, employees, citizens." 194 However, it also has favored the haves at the expense of have-nots by binding parties to standard-form contracts that, among other things, waive employees' rights to litigate civil rights claims and concede to jurisdiction so far away that litigation becomes practically impossible. ${ }^{195}$ The status/contract dichotomy evidences similar complexity in the polygamy debates.

Status and contract evade precise definition. However, the notion of innate, hierarchal status underlies assertions by scientific racists like Roberts Barthelow, Samuel Cartwright and C.G. Forshey equating polygamy with backward and degenerate races. ${ }^{196}$ Contract, representing choice and equality, informed antipolygamists' assertion that Mormon

${ }^{191}$ Id. at 151 (describing how "modern jurisprudence, forged in the furnace of barbarian conquest, ... . has absorbed . . . those rules concerning the position of women which belong peculiarly to an imperfect civilization. ... [T] he women of the dominant races are seen everywhere under various forms of archaic guardianship.”).

192 Id. at $121,145,163$.

193 See, for example, THE Progressive, a magazine which bills itself as supporting “peace and social justice.” http://www.progressive.org/ (visited Mar. 1, 2010).

194 Sarah Barringer Gordon, The Liberty of Self-Degradation: Polygamy, Woman Suffrage, and Consent in Nineteenth-Century America, 83 J. AM. HIst. 815, 833 (1996).

195 See e.g., Carnival Cruise Lines v. Shute, 499 U.S. 585 (1991); Gilmer v. Interestate/Johnson Lane Corp., 500 U.S. 20 (1991).

196 See supra Part II.C. 
women were forced into plural marriage. But the cartoons show that antipolygamists did not champion choice and equality for everyone. Instead, the cartoons condemn the choice of interracial marriage, and the equality it both presupposes and supports. Thus contract provides a way to decode the otherwise puzzling miscegenation references in polygamy cartoons.

Miscegenation anxiety played a central role in nineteenth century white supremacy. ${ }^{197}$ After the Civil War, courts and legislatures defined, and then redefined, the contours of Black Americans' citizenship through their decisions first to invalidate miscegenation law, and then to reinstate it. ${ }^{198}$ As a whole, the cases show a brief step from status to contract and quickly back again toward status.

In the wake of the Civil War, courts and legislatures in seven of the eleven formerly confederate states invalidated or repealed their miscegenation statutes. ${ }^{199}$ These courts reasoned that marriage was a civil contract and that the Civil Rights Act of 1866 and the Fourteenth Amendment protected African Americans' right to contract on the same basis as White citizens, rendering the miscegenation laws unenforceable. In Burns v. State, for example, the Alabama Supreme Court held the state miscegenation statute unconstitutional, reasoning that because marriage is a civil contract, " $[t]$ he same right to make a contract as is enjoyed by white citizens means the right to make any contract which a white citizen may make." ${ }^{200}$ But the triumph of contract over status in marriage was short lived. Indiana led the retrenchment by upholding its miscegenation law in State v. Gibson. ${ }^{201}$ The court began by reasoning that Blacks' contractual freedoms guaranteed by federal law extended only to the District of Columbia and "other places where the federal government has exclusive jurisdiction," meaning territories and the unreconstructed South. ${ }^{202}$ It finished by rejecting freedom of contract as a rationale for overturning miscegenation law, asserting that marriage, while contractual, was "more than a mere civil contract”:

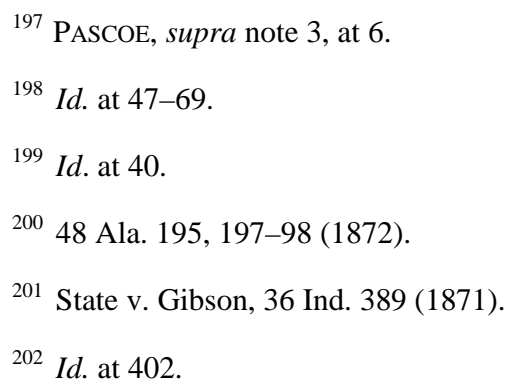


In this State, marriage is treated as a civil contract, but it is more than a mere civil contract. It is a public institution established by God himself, is recognized in all Christian and civilized nations, and is essential to the peace, happiness, and well-being of society .... The right, in the states, to regulate and control, to guard, protect, and preserve this God-given, civilizing, and Christianizing institution is of inestimable importance, and cannot be surrendered. ${ }^{203}$

Indiana, as a Northern state, could hardly be accused of trying to resurrect slavery by so narrowly interpreting the post-Civil War Amendments and legislation. Southern states embraced the Indiana Supreme Court's analysis as, one by one, they reinstated their miscegenation bans. ${ }^{204}$

When the Supreme Court sided with the opponents of so-called "race mixing" in Pace v. Alabama, status triumphed over contract's temporary progress. ${ }^{205}$ Bans on miscegenation remained, providing a backbone of racial hierarchies until late into the twentieth century. ${ }^{206}$ In short, ideas of contractual freedom provided an intellectual framework for allowing interracial marriage. But these ideals about choice and equality were quickly stifled by status-based ideas about racial status, effectively limiting full civic membership to Whites.

It is no coincidence that the country wrestled with the miscegenation question and the Mormon question at the very same time, in the decades after the Civil War. Supporters of polygamy, like those seeking to overturn miscegenation laws, made contractual freedom arguments. As with miscegenation, those contractual arguments lost out to status-based ones. In 1859, three years before Congress passed its first antipolygamy statute, John Stuart Mill, among the most prominent philosophers of his day, devoted the last few pages of his classic text On Liberty to a contractualist defense of plural marriage. ${ }^{207}$ Briefly put, Mill argued that the State should leave people free to make choices, even bad choices, since the State was no better situated, and often less able, than people to make those

${ }^{203}$ Id. at 403.

${ }^{204}$ PASCOE, supra note 3, at 62-63.

${ }^{205}$ Id. at 115 (citing Pace v. Alabama, 106 U.S. 583 (1882)).

${ }^{206}$ Loving v. Virginia, 388 U.S. 1 (1967).

207 John Stuart Mill, On LiBerty 152-54 (David Bromwich \& George Kateb eds., Yale Univ. Press 2003) (1859). 
decisions for themselves. ${ }^{208}$ While acknowledging the harm polygamy could pose to women, he reasoned that interfering with Mormon women's choice would impose a greater tyranny:

[I]t is difficult to see on what principles but those of tyranny they can be prevented from living there [in Utah] under what laws they please, provided they commit no aggression on other nations, and allow perfect freedom of departure to those who are dissatisfied with their ways. ${ }^{209}$

Granted, Mill leaves room for debate. The extreme measures the federal government took to force Mormons to abandon polygamy could well be justified by the Mormons' "aggression on other nations"-at least the United States - and the Mormons' refusal to "allow perfect freedom of departure" for those who preferred monogamy. ${ }^{210}$

The slipperiness of status and contract may be due to the fact that they are social constructs, and thus changeable. ${ }^{211}$ But important distinctions separate the two. Status is constructed to deny its social construction, claiming instead to derive its substantive rules from an extrahuman source of authority-usually God, nature, or biology-rather than human beings. ${ }^{212}$ Thus the Indiana Supreme Court could describe marriage as "God-given ... . and Christianizing" at the very moment it imposed human-made rules to define it as monoracial. ${ }^{213}$ The court avoided dismantling race hierarchy by viewing it as "God-Given," and thus beyond human authority, perhaps even beyond human understanding. Contract, in

${ }^{208}$ Id.
${ }^{209}$ Id. at 154.
${ }^{210}$ See Part I.A, supra.
${ }^{211}$ The status-based rules regarding children, such as child labor and the age of consent, and disabled people, for example, have changed considerably in the last century. David M. Engel \& Frank W. Munger, Rights of InClusion: LAW AND IDENTITY IN THE Life Stories of Americans with Disabilities (2003); Viviana A. Zelizer, Pricing the PRICEless ChILD (1984). See also Americans with Disabilities Act of 1990, 42 U.S.C. $\S \S$ 12101-12213 (2000).

212 Slavery, the most extreme status-based work system, assigned Whites the status of masters and African Americans the status of things. Master and slave could not switch roles. In contrast, contractual wage labor, in theory, allows a worker to ascend from secretary to middle manager, perhaps even all the way up to company president.

${ }^{213}$ State v. Gibson, 36 Ind. 389, 403 (Ind. 1870). 
contrast, owns its social construction by deriving its authority from human action. Thus Elizabeth Cady Stanton's assertion that "if you regard marriage as a civil contract, then let it be subject to the same laws which control all other contracts." 214

In both miscegenation and polygamy debates, the status-based construction of marriage as monogamous and mono-racial made important contributions to the construction of citizenship as White. In each dispute, contractual reasoning might have lead to a different-and more progressive_-result of allowing people to choose their spouses, regardless of race, or in Mill's words, to live in Utah "under what laws they please, provided they commit no aggression on other nations, and allow perfect freedom of departure to those who are dissatisfied with their ways. ${ }^{215}$ But status prevailed.

Using Henry Maine's sense of "progressive” as moving forward, and "status" as stationary, the resolution of contests over race and numerosity in marriage pushed citizenship backward. Seen this way, monogamists who charged polygamists with being throwbacks, and selfstyled "race purists" who viewed people of color as backward, were themselves defending, and reinstating a primitive notion of citizenship based on racial status.

This primitive defense of status played a key role in other discussions of race and gender. Slaveholders invoked the Biblical story of Noah cursing his son Ham to argue that Black Africans were descended from Ham, and thus "originally designed to vassalage." ${ }^{216}$ William Blackstone justified common law coverture rules with a Biblical passage, asserting that man and woman are "one flesh" before God. ${ }^{217}$ By the late twentieth century, contractualist opposition to both of these status-based

214 James W. Fox, Jr., The Law of Many Faces: Antebellum Contract Law as the Background of Reconstruction-Era Freedom of Contract, 49 AM. J. LEG. HisT. 61, 105 (2007) (quoting Elizabeth Cady Stanton, Address to the Legislature of New York, adopted by the state Women's Right's Convention, held at Albany, Feb. 14 \& 15, 1854, at 8-9).

${ }^{215}$ MAINE, supra note 13, at 154.

${ }^{216}$ Daniel M. Goldenberg, The Curse of Ham: Race and Slavery in Early JUDAISM, EARLY CHRISTIANITY AND ISLAM 1 (2003). Similarly, a group of nineteenth century anthropologists coined the term "polygenist" to contend that Caucasians and Africans were different species of the same genus, with Africans naturally suited to subordination. See, e.g., Louis Menand, The Metaphysical Club 116 (2001).

${ }^{217}$ Norma Bosch, In the Eyes of the LAW: Women, MARriage \& Property IN Nineteenth Century New York 22 (1982) (quoting 1 William Blackstone, CommentARIES ON THE LAWS OF ENGLAND 430, 432 and Genesis 2:24 (RSV)). 
lines of argument ripened into doctrines allowing interracial marriage, premarital contracting, and no-fault divorce. ${ }^{218}$ But all along the way, defenders of status resisted contractualism. In this framework, the antipolygamy cartoons can be seen as yet another visceral defense of status.

\section{Viscerally Defending Status to Ward off Private Ordering}

Legal academics refer to the contractualism within Henry Maine’s framework as "private ordering," which honors individual choice and produces more pluralism. ${ }^{219}$ The phrase "private ordering" as shorthand for contractualism helps decode the pervasive disorderliness in antipolygamy cartoons. They depict political disorder through despotism, racial disorder through miscegenation, and domestic disorder through unmanageable ratios of men to women and children, disrespect for parental authority, and lasciviousness. The morality tale repeated ad nauseum in these cartoons cautions against plurality and equality. Yet the complexity of how consent (and thus contractualism) played out in polygamy debates offers its own lesson about facile assertions that one form of marriage is more contractual or status-oriented than the other.

Both polygamy and monogamy mixed status and contract, but in different ways. ${ }^{220}$ Legal historian Sarah Gordon deftly maps convergences between freedom of contract strains of antipolygamy, abolitionist, and suffragist rhetoric. ${ }^{221}$ In her view, nineteenth century Americans treated consent as "both highly valued and tightly confined," producing a "vapid" notion of consent in antipolygamy rhetoric that merely triggered entry into an authoritarian relationship, a far cry from "the individual will and sovereignty that its defenders claimed to cherish."222 Antipolygamists and abolitionists, she explains, condemned the "twin relics" as nonconsensual:

218 See, e.g., Loving v. Virginia, 388 U.S. 1 (1967); Marvin v. Marvin, 557 P.2d 106 (Cal. 1976); Michael Grossberg, Governing THE HeARTH 20-24 (1985); JoHN WitTE, Jr., From Sacrament to Contract: Marriage, Religion and the LAW in the Western TRADITION 10-12 (1997).

219 See, e.g., IAN Ayres \& John Braithwaite, Responsive REgulation: Transcending the Deregulation Debate 3 (1992); IAn Ayres, Pervasive Prejudice (1988); RoBERT ELLICKSON, ORDER WithOUT LAW (1992).

220 The complexity of consent in marriage may well stem from classical liberalism's gendered notion of consent, in which men consented to governments, and women consented to husbands. CARole Pateman, The SeXual Contract (1988).

\footnotetext{
${ }^{221}$ Gordon, supra note 203, at 832-47.

${ }^{222}$ Id. at 832, 846-47.
} 
Marriage and wage labor-these were the essential private rights that abolitionists subsumed under the "freedom of contract" label. . . . These were the voluntary legal relations denied slaves. Antipolygamists argued that the legal restrictions of slavery were replicated for women in Utah. Like slaves, Mormon women were denied the most important legal privileges, charged antipolygamists; the tyranny of Mormon men undermined their ability to contract valid marriages. ${ }^{223}$

Yet the domestic relations doctrines governing the monogamous marriages that antipolygamists so staunchly defended remained steeped in statusbased reasoning.

The common law doctrine of coverture treated marriage as a status into which women contracted. ${ }^{224}$ Once married, they lost their legal identity under the theory that they became united in one person with their husband, their husbands representing them in voting, entering contracts, and other acts of civic membership. ${ }^{225}$ In this legal universe, spouses could divorce only in extreme circumstances such as one person committing a crime like adultery. ${ }^{226}$ Still, monogamy was beginning to evolve away from status and toward contract through statutes like the Married Women's Property Acts. $^{227}$

Contrary to antipolygamists' condemnations of the lack of consent inherent in polygamy, the legal doctrines governing polygamy actually extended a measure of procedural freedoms of contract by relaxing requirements for divorce. ${ }^{228}$ In 1852, Utah passed the most permissive

${ }^{223}$ Id. at 832 .

${ }^{224}$ BLACKSTONE, supra note 227, at 430.

225 Norma Basch, In the Eyes OF THE LAW: WOMEN, MARRIAGE AND PROPERTY IN NINETEENTH CENTURY NEW YORK (1982).

${ }^{226}$ Gordon, supra note 203, at 836.

${ }^{227}$ See, e.g., 1809 Ohio Laws 146.( "[A]nd every female person aged eighteen years and upwards . . . shall have power . . . to devise all the estate, right, title . . . to lands . . ..”.

${ }^{228}$ Procedural aspects of contractual freedom concern entry and exit from the relation, as opposed to substantive freedoms to determine the terms of a contract. See Arthur Allen Leff, Unconscionability and the Code: The Emperor's New Clause, 115 PENN L. REV. 485 (1967) for a discussion of procedural and substantive unconscionability. Mormons themselves acknowledged the old-fashioned status-based elements of polygamy, calling it the "Patriarchal Principle" to reflect their emulation of Old Testament patriarchs. GORDON, supra note 16, at 3. For further discussion of Mormons' assertions of themselves as superior in status-based terms, see supra III.C.1. 
divorce statute in the entire country. ${ }^{229}$ It allowed anyone who was "a resident or wishes to become one" to obtain a divorce if "it shall be made to appear to the satisfaction and conviction of the court, that the parties cannot live in peace and union together, and that their welfare requires a separation." 230 Most provocatively for present purposes, Gordon suggests that Americans' common tendency to speak of the government as a national household meant that antipolygamists may well have viewed Utah's lax divorce statute as akin to the South's threats to separate from the Union:

[I]t is . . . worth exploring the contours of consent in the era of the Civil War, a war fought to preserve a union created by the consent of the parties from dissolution when one party sought to withdraw, arguing that it no longer consented to the marriage. Unionists argued, and fought for, the proposition that a constitution, like a marriage, was more than a compact formed with the possibility of dissolution in view. ${ }^{231}$

This link between polygamy, divorce and secession reveals that monogamy was more procedurally status-based than its proponents let on. Overall, antipolygamists condemned plural marriage as overly contractual or overly status-based, whichever made the Mormons look worse. Their arguments succeeded in part because polygamy, like monogamy, was a mixed bag of status and contract.

Doctrinally, Utah's rule allowing free exit from marriage represented procedural contractualism in marriage, since spouses could leave (and presumably form another contract with a new spouse). The divorce law reflected a certain moral neutrality toward various marriage forms that reflected pluralist norms produced by contract-based thinking. ${ }^{232}$ But substantively, plural marriage was defined by the status-based version of coverture that held sway in upstate New York in the 1830s when Joseph Smith founded the religion, a view reinforced by Mormon leaders' authoritarian control over the membership. ${ }^{233}$

\footnotetext{
${ }^{229}$ Gordon, supra note 203, at 842 .

${ }^{230} I d$.

${ }^{231}$ Id. at 838.

${ }^{232}$ Mormon scripture expressed no such moral neutrality, mandating damnation for women who refused to consent to their husbands taking a plural wife because they opposed plural marriage. GoRDON, supra note 16, at 96.

${ }^{233}$ DAYNES, supra note 37, at 17.
} 
The status-enforcing aspects of Mormon contractualism in marriage become clear upon close examination of purported freedoms like the liberal divorce statute. Utah lawmakers likely passed this statute to enable Mormon converts to divorce their non-Mormon spouses and marry Mormons. ${ }^{234}$ Moreover, liberal divorce may have represented freedom for husbands but more constraints than ever on wives, because they had to obey dictates of husband or Church or risk abandonment. As Brigham Young explained in an 1856 sermon:

My wives have got to do one of two things - either round up their shoulders and endure the afflictions of this world and live their religion, or they may leave; for I will not have them about me. I will go into heaven alone, rather than have scratching and fighting around me. I will set all at liberty. What! first wife too? Yes, I will liberate you all. ${ }^{235}$

Two incidents involving founding prophet Joseph Smith further demonstrate the highly constrained "consent" in plural marriage.

Lucy Walker wrote that Mormon Prophet Joseph Smith told her in 1842 "I have a message for you. I have been commanded of God to take another wife, and you are the woman." ${ }^{, 36}$ He then asked if she believed him to be "a prophet of God," to which she assented, then he explained that plural marriage would "prove an everlasting blessing." ${ }^{237}$ After deliberating, she married him. ${ }^{238}$ Another incident involving Joseph Smith shows that some Mormon women did not freely consent to plural marriage. Obedience was so central to Mormon practice that refusal to enter a plural marriage could be deemed traitorous to the Mormon project. When Joseph Smith taught Mary Rollins Lighter about plural marriage, and she hesitated, he asked her if she "was going to be a traitor." 239 Perhaps reluctant to betray the charismatic leader of her isolated community, she became a plural wife. ${ }^{240}$

\footnotetext{
${ }^{234}$ Gordon, supra note 203, at 842.

${ }^{235}$ Id. at 835.

${ }^{236}$ DAYNES, supra note 37, at 27.

${ }^{237}$ Id.

${ }^{238}$ Id. at $27-28$.

${ }^{239}$ Id. at 26-27 (emphasis in original).

${ }^{240} I d$.
} 
In short, the practice of nineteenth century monogamy offered women a measure of procedural contractual freedom by choosing a mate and substantive contractual freedom through statutory reforms like the Married Women's Property Acts. But overall, monogamous marriage retained status-based doctrines by sharply restricting spouses' freedom to alter the substantive terms of the state-created marriage contract and limiting access to divorce. Polygamy, in contrast, implemented a measure of procedural contractualism by facilitating divorce, but similarly retained, and perhaps strengthened, rigid status-based hierarchies that defined the substance of marital, and perhaps other relationships.

The quantum of contract and status in monogamy and polygamy can also be reversed. Monogamy becomes more status-oriented by virtue of its immutability, which precludes "contracting" around it for another kind of marriage (or contracting around mono-racial norms to form an interracial marriage). Polygamy, in contrast, seems more contractual by presupposing a "moral diversity"241 of marital options, and allowing Mormons to engage in private ordering by "contracting" around the default rule of monogamy. ${ }^{242}$ While the status-based elements of polygamy may have made for less equality within those marriages, this contractual rubric makes for more equality among types of marriage. Doctrines governing monogamy, in contrast, provided an increased measure of equality for women within marriage over the course of the century, but less equality among different types of intimate affiliation.

These themes found expression in best-selling antipolygamy novels, often written by women, which likely influenced the ban on Mormon polygamy:

For antipolygamy reformers, the most compelling proof of the barbarism of both slavery and polygamy was the brutal indifference both showed to marriage as the sanctification of a woman's powers of sexual consent. Just as the slave plantation had been a deviant family, a seat of "fornication, adultery,

\footnotetext{
${ }^{241}$ Sarah Barringer Gordon, "Our National Hearthstone”: Anti-Polygamy Fiction and the Sentimental Campaign Against Moral Diversity in Antebellum America, 8 YALE J.L. \& HUMAN. 295, 300 (1996).

${ }^{242}$ If, however, Church mandate determines whether a person exercises this option to "contract around" monogamy, it ceases to be contractual, except to the extent that a person might “contract” out of mainstream Christianity and into Mormonism by converting.
} 
concubinage,” the family under polygamy, its critics charged, was "white slavery."243

Antipolygamists' insistence that no sane White woman would ever consent to plural marriage conflicted with many polygamist women's insistence that they willingly became polygamous wives, ${ }^{244}$ and also with the antipolygamists' tolerance for the limited role of consent within monogamy. As a matter of legal doctrine, marital rape was not recognized until a century after the Reynolds case, because rape was defined as intercourse by force and without consent, with a woman not the defendant's wife. ${ }^{245}$ Literary critic Nancy Bentley explains:

[F]emale consent represented a form of social legitimation that had become both indispensable and problematic for the modern nation-state. Indispensible because, as a model for social relations, wifely consent could soften the constraints of law and duty into the joys of love; problematic because the passivity of wifely love made it an inherently equivocal model of political agency. $^{246}$

The social legitimization of women in the nation state was indeed equivocal. When state legislatures passed Married Women’s Property Acts, courts narrowly interpreted them to limit wives' access to earnings. ${ }^{247}$ Just seven years before deciding Reynolds, the Supreme Court upheld Illinois' refusal to allow women to practice law, reasoning that wives could not hold careers independent of their husbands. ${ }^{248}$

Perhaps this very tension, between monogamist women's desires for a greater measure of consent—and even individuality—in marriage, and the very real constraints monogamy placed on both female consent and

${ }^{243}$ Bentley, supra note 92, at 346 (quoting STANLEY, supra note 35, at 24).

${ }^{244}$ Id. at 346 .

245 The Model Penal Code still defines rape as forcible "sexual intercourse with a woman not [the defendant's] wife ....” Model PenAl Code $\S$ 213.1. See Robin West, Equality Theory, Marital Rape, and the Promise of the Fourteenth Amendment, 42 U. FLA. L. REV. 45 (1990).

246 Bentley, supra note 92, at 348.

${ }^{247}$ Reva B. Siegel, The Modernization of Marital Status Law: Adjudicating Wives' Rights To Earnings, 1860-1930, 82 GEO. L.J. 2127, 2210 (1994).

${ }^{248}$ Bradwell v. Illinois, 83 U.S. 130, 141 (1873) (Bradley, J., concurring). 
individuality, fueled that branch of the antipolygamy movement. Bentley suggests that in the face of their own all-too-seldom ideal domestic arrangements, antipolygamist women could use Utah polygamy to "draw off every historical and personal ambiguity of wifehood, estranging and finally displacing those ambiguities onto the sins of an occidental Sodom, a collection of "unbelievable crimes in a far off country."249 If we drag our disinherited selves behind us, nineteenth century antipolygamists could be said to have dragged their disinherited notions of status in marriage behind them, vehemently distinguishing their current selves from the very status regimes they were slowly leaving behind.

\section{Viewing Cartoons through a Lens of Status and Contract}

This profound agnosticism about polygamy's relationship to gendered status arrangements also appears in cartoons. Some cartoons decried polygamy as treating women like things. One cartoon published in the Daily Graphic in the early 1880s depicts a Mormon polygamist as a pirate with wives tied to his belt like so much booty. ${ }^{250}$

249 Bentley, supra note 92, at 352 (quoting Alva Milton KerR, Trean, OR The Mormon's Daughter: A Romantic STORY OF LifE AMONG THE LATTER-DAy SAINTS 65 (1888)). James Baldwin discerned a similar pattern in mid-twentieth century racism. In his view, White people project their darkest desires and most egregious flaws onto African Americans, then cannot view them as fully human without giving up the fantasy of their own purity and innocence. James Baldwin, The Fire Next Time, in BALDwin: Collected EsSAYs 340-42 (ed. Toni Morrion 1998).

${ }^{250}$ Defiance, The Daily GraPhic, reprinted in GoRdon, supra note 16, at 13. 


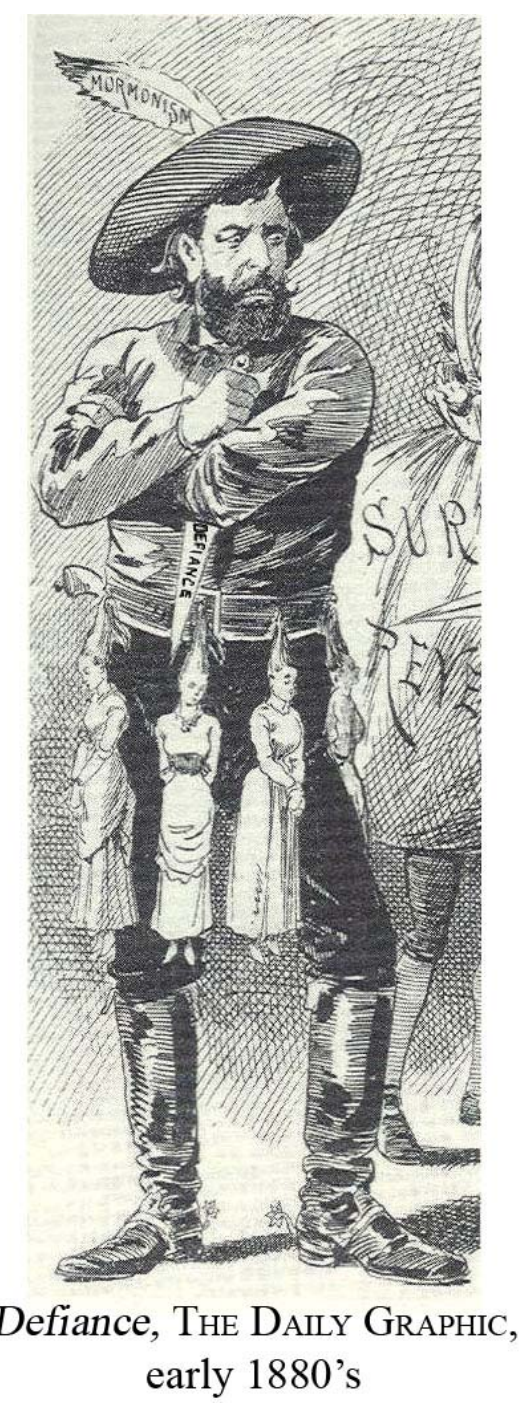

Yet more is going on in the cartoon. In addition to conveying the disorder of too much male power, the feather in his cap labeled "Mormonism" may signal Native American resistance to Federal incursion, ${ }^{251}$ as well as Mormon propensities to savagery and even murder. ${ }^{252}$ This theme of

${ }^{251}$ Recall that Mormons collaborated with Indians to murder 127 travelers in the Mountain Meadows Massacre in 1857. See supra note 58 and accompanying text.

${ }^{252} I d$. 
political disorder carries over to the pirate's dagger, labeled "defiance," bringing to mind the possibility of simultaneous fascination with the romantic freedoms of piracy and condemnation of its social dangers.

Similarly, an 1882 cartoon in The Judge, titled "An Unsightly Object," 253 mined the common view of polygamy and slavery as the "twin relics of barbarism” by depicting polygamy like a slave auction in which beleaguered White women wore numbers as if they were chattel for sale.

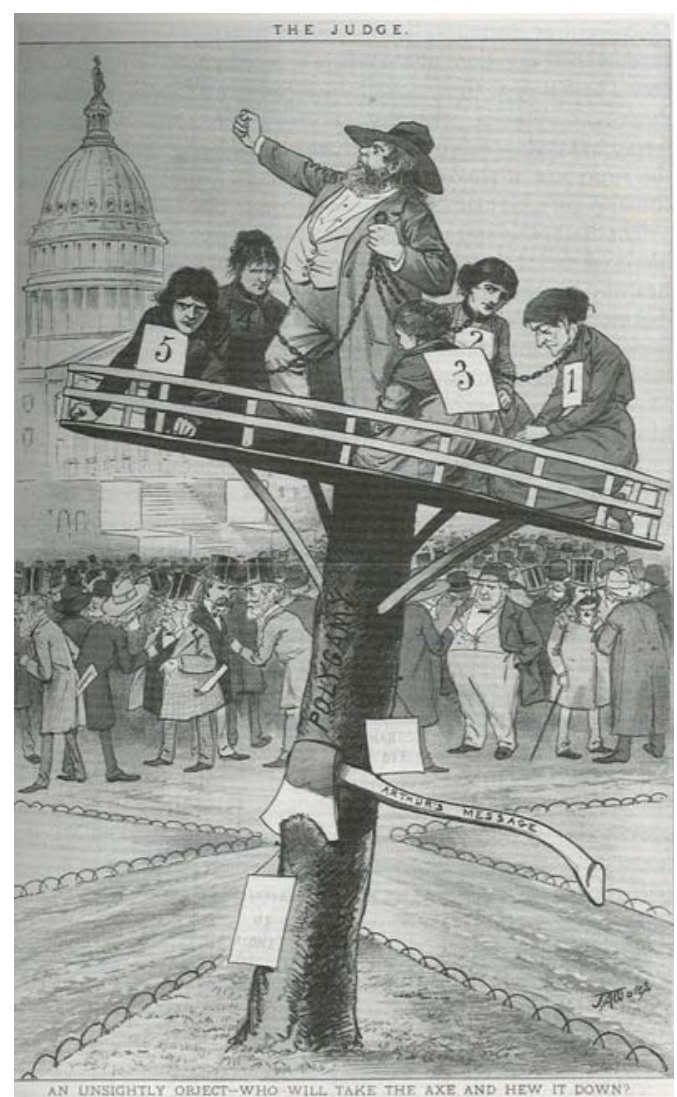

An unsightly object-who will take the axe and hew it down? The Judge, Jan. 28, 1882

A closer look reveals many ideas beyond accusing polygamy of treating women like things. Notice the fat polygamist's defiance: he shakes his fist

${ }^{253}$ An Unsightly Object, THE JUDGE, Jan. 28, 1882, reprinted in GORDON, supra note 16 , at 3 . 
at the federal capitol building, and resembles the wild Irishman in the cartoon titled "An Irish Jig" from Harpers discussed above. ${ }^{254}$ This cartoon, "An Unsightly Object," like "Uncle Sam's Troublesome Bedfellows,",255 argues for increased legal action against the Mormons. An ax labeled "[President] Arthur's Message" is embedded in the stump labeled "polygamy," but the men in top hats are milling around instead of paying attention. Implicitly, words alone will not "hew down" the unsightly stump of polygamy: federal force is needed.

The federal government eventually asserted enough force to win the battle over Mormon polygamy. ${ }^{256}$ However, what it was attacking and defending remains open to debate. Sarah Gordon convincingly frames the federal action against the Mormons as the second half of Reconstruction, exercising new-found federal authority in Utah just as the North withdrew from the South in the 1870s. ${ }^{257}$ Nancy Cott views it as one moment in the construction of citizenship through marriage as White, monogamous, and married. ${ }^{258}$ A third view, proposed here, views citizenship is as status, reinscribed with hierarchies of race and sex at the very moment after the Civil War when both might have been radically altered. That alternation can be described as contractual, grounded in ideals of equality, autonomy, and pluralism. Two cartoons from the early twentieth century demonstrate this underlying concern that polygamy could empower women and people of color.

A 1904 cartoon in New York World, captioned "There are Influences Greater than the Government in Utah,"259 echoes the old joke of one wizened old polygamist dominated by numerous wives, ${ }^{260}$ and also brings to mind public events of the early twentieth century in which women sought the vote.

\footnotetext{
${ }^{254}$ See supra notes 101-102 and accompanying text.

${ }^{255}$ See supra note 93 and accompanying text.

${ }^{256}$ See supra note 27.

${ }^{257}$ GoRDON, supra note 16, at 14.

${ }^{258}$ CoTT, supra note 17 , at 121.

259 There are Influences Greater than the Government in Utah, NEW YORK WORLD, 1904, reprinted in BUNKER \& BITTON, supra note 78, at 133.

${ }^{260}$ See supra Part III.C.
} 
[Vol. 19:2

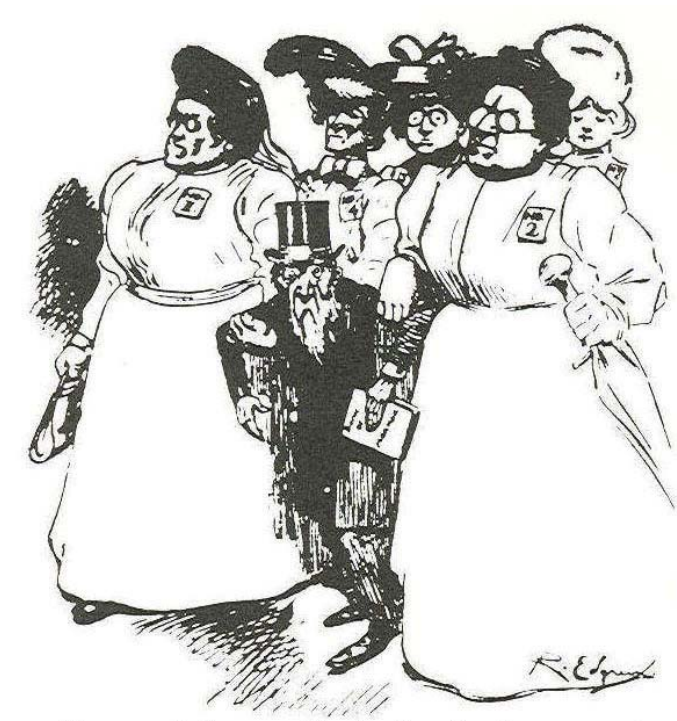

There are Influences Greater than the Government in Utah, New York WorLd, 1904

The cartoon may well have meant to depict polygamy as an institution so strong it could overpower the state ban on it. Additionally suggested are the dangers posed by powerful women seeking public rights. Utah had granted women the vote in 1870, before Congress disenfranchised Utah women through the Edmunds Tucker Act in $1887 .{ }^{261}$ An 1899 article in the AfroAmerican charged feminists, proponents of free-love, and polygamists with waging war "against the marriage institution." 262 By 1904, Utah women had been voting for a decade, by virtue of new state's constitution, which had restored female suffrage. ${ }^{263}$ New York, presumably home to most readers of the New York World, was much more hostile to women voting than Utah, withholding suffrage from women until $1917 .{ }^{264}$

Viewing the cartoon through the lens of women's rights is revealing. The first wife, who is labeled "No. 1" on the left, holds a pocketbook. If she also holds a job at a factory in one of the newly industrialized cities, most states would allow her to control her own earnings. On the right, and

\footnotetext{
${ }^{261}$ See supra note 26.

262 Afro-American, Sept. 23, 1899, at 4.

${ }^{263}$ Lynda G. Dobbs, Parades, Pickets and Prisons: Alice Paul and the Virtues of Unruly Constitutional Citizenship, 24 J. L. \& PoL. 339, 361 (2008).

${ }^{264}$ Eleanor FleXner, CENTURy OF Struggle 289 (Belknap 1996) (1959).
} 
equally formidable, is a bespectacled matron holding an umbrella. She looks ready to read, ready for rain, and ready to take to the streets for woman suffrage. In the background is a single ugly woman with bug eyes, repeating the old saw about ugly women and polygamy. As a whole, the cartoon seems to mourn the loss of some status-based hierarchies in marriage, and long for the day where one man might assert his rightful place of head of household, without worrying about his wife (or wives) wielding economic, political, or social power.

A year later, in 1905, sheet music for a song titled The Mormon Coon, similarly used polygamy to ridicule changes to status-based arrangements, this time along race lines. ${ }^{265}$

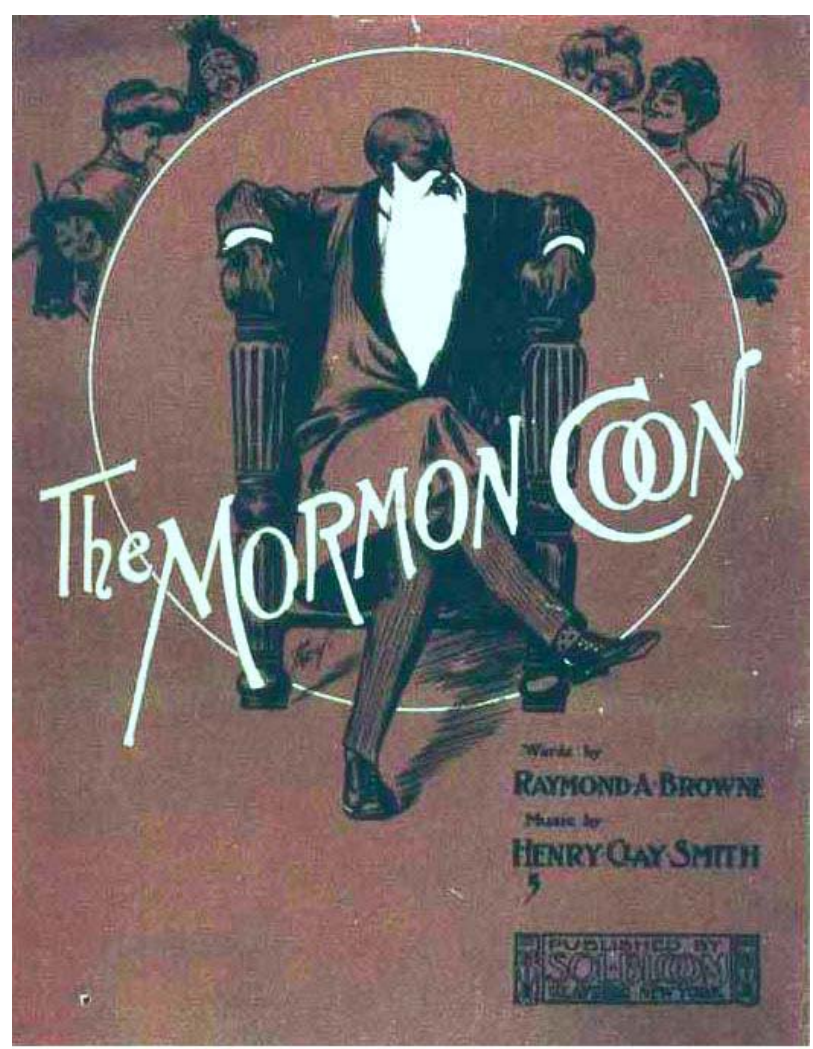

The Mormon Coon (1905)

265 The Mormon Coon, 1905, reprinted in BUNKER \& BITTON, supra note 78, at 89. 
The image on the sheet music cover brings to mind the Supreme Court's language in Reynolds associating polygamy with both despotism and "Asiatic and African peoples." ${ }^{266}$ Unlike most nineteenth century satiric portrayals of polygamists, in which one wife or child might be Black, this image portrays the polygamist man himself as Black. But he is also Asianlooking, with almond shaped eyes and a long, silky-looking white beard and mustache. As in earlier cartoons, he is surrounded by his many wives, one Asian, a few Anglos, one unattractive woman, and the easily recognized mammy figure waving on the far right. The "Mormon Coon" sits imperiously on his throne, governing his numerous and diverse family. The core jibe is that he may even govern the state. The lyrics begin with usual joking reference to numerosity and racial mixing, adding in the old gem about ugly plural wives:

I'm out in Utah, in the Mormon land,

And going to stay, because I'm living grand,

I used to rave about a single life,

Now every day I get a brand new wife.

I've got a big brunette, And a blonde to pet,

I've got 'em short, fat, thin and tall,

I've got a Cuban gal, and a Zulu pal,

They come in bunches when I call

And that's not all-I've got 'em pretty too

Got a homely few,

I've got 'em black to octoroon,

I can spare six or eight, Shall I ship 'em by freight?

For I am the Mormon coon. ${ }^{267}$

As the song progresses, it ridicules Black political and economic citizenship as well as intelligence:

Next fall they'll make me Gov'nor of the State;

The Parsons give me commutation rate;

I wish for every wife I had a cent,

Why, just for photographs, a house I could rent.

I've got so many, I forget a lot,

I keep the marriage license door hot,

\footnotetext{
${ }^{266}$ Reynolds v. United States, 98 U.S. 145, 164 (1879).

${ }^{267}$ Raymond A. Browne \& Henry Clay Smith, The Mormon CoOn (Sol Bloom
} 1905) (copy on file with author). 
If on the street into a wife I run,

I have to ask her, "What's your number, Hon?"268

This music likely milked the renewed interest in Mormon polygamy due to the drawn-out hearings then occurring over Mormon Reed Smoot's Senate seat. ${ }^{269}$ Yet the oft-repeated jabs at numerosity, racial and national diversity, adding ridicule for Black political power, suggest that the cartoon mined deeper territory. The persistence of these claims suggests they formed a foundation for the ban on polygamy, leaving us to ask, a century later, what currently justifies polygamy law. Most important is whether we, like our nineteenth century predecessors, continue to carry concerns about foreignness, barbarism, and racial degeneration, still embedded deep inside polygamy law.

The Mormon Coon, like other cartoons and the language of Reynolds asserting that polygamous societies "fetter[] the people in stationary despotism" 270 explicitly linked race hierarchy to monogamy. Requiring monogamous marriage within citizens' households, while facially neutral, was deeply raced. ${ }^{271}$ Slaves could not marry and patterns of intimacy in slave communities included a range of affiliations, including marriage, "taking up," and "sweethearting," that structured enslaved people’s lives. ${ }^{272}$ In American Apartheid, marriage has often defined

\footnotetext{
${ }^{268} I d$.

${ }^{269}$ GoRDON, supra note 16, at 235.

${ }^{270}$ Reynolds v. U.S., 98 U.S. 145, 165-66 (1879).

${ }^{271}$ Marital form has long been linked to citizenship. In 1806, Napoleon convened
} an Assembly of Jewish Notables "to revive among the Jews . . . the sentiments of civil morality that unfortunately have been moribund among too large a number of them by a state of abasement in which they have long languished." HOWARD M. SACHAR, THE COURSE OF MODERN JEWISH HISTORY 47 (rev. ed. 1990). His representative asked these prominent Jews to answer twelve questions with answers showing them "worthy" or enjoying "the totality of their rights as Frenchmen." Id. The first question was "Are the Jews permitted to have more than one wife?” Id. The Notables' response, including reassurances that Jews were monogamous, satisfied Napoleon. Id. at 48-49.

272 American citizenship, of course, as long been both gendered and racialized. KATHERINE M. FrANKe, EMANCIPATION APPROXIMATION (forthcoming 2010); Katherine M. Franke, Becoming a Citizen: Reconstruction Era Regulation of African American Marriages, 11 Yale J.L. \& Human. 251 (1999); Leti Volpp, Divesting Citizenship: On Asian American History and the Loss of Citizenship Through Marriage, 53 UCLA L. REV. 405 (2005). 
citizenship, and Whiteness (actual or perceived) has often determined whose marriage counted. ${ }^{273}$

Re-reading Reynolds in this light invites us to rethink our knee-jerk opposition to polygamy. The historian David Halperin observed that some messages are so common that they don't even have to be delivered, only activated. ${ }^{274}$ Think of stereotypes such as gay male pedophiles or thieving welfare queens. These implicit designations of "us" as better than "them" determine the outcome from the outset: people-designated "problems" must be subjected. This pattern played out in Reynolds' case. On appeal from the trial court, the Utah Supreme Court upheld Reynolds' conviction, summarily rejecting religious freedom claims as "based upon neither reason, justice, nor law." 275 On appeal to the U.S. Supreme Court, Reynolds' attorneys filed a sixty-three page brief making extensive religious freedom arguments. ${ }^{276}$ The government's brief, in contrast, was only eight pages long, explicitly declining to address the religion claim by asserting that it did not "call for any remark." 277 The Supreme Court's unanimously upheld Reynolds' bigamy conviction. ${ }^{278}$

But the untold story of race and American polygamy law does call for remark by those who think that legal doctrine needs better justification than racialized assertions that "we" are better than "them." This Article concludes with a brief précis of how Americans could reexamine the ban.

\section{THREE QUESTIONS FOR RETHINKING POLYGAMY}

Three questions help us rethink the polygamy ban. First, even if the ban is rooted in white supremacy, why rethink a ban that is rarely enforced and affects only eccentric religious sects in remote areas? Second, do we still associate plural marriage with barbarism, foreignness, and people of color? Third and finally, is it a coincidence that the plain language of the

\footnotetext{
${ }^{273}$ See PASCOE, supra note 3, at 6-7.

${ }^{274}$ Ruskola, supra note 11, at 185 (quoting DAVID M. HALPERIN, ST. FouCAUlT: TOWARDS A GAY HAGIOGRAPHY 13 (1995)).

${ }^{275}$ United States v. Reynolds, 1 Utah 226, 226 (1875).

2768 LANDMARK BRIEFS AND ARGUMENTS OF THE SuPREME COURT OF THE UNITED

${ }^{277}$ Id. at $67,75$.

${ }^{278}$ Reynolds v. United States, 98 U.S. 145 (1879).
} STATES 3 (1975) 
Defense of Marriage Act (DOMA) bans both polygamy and same-sex marriage?

The first question invites us to examine the expressive function of banning polygamy, since that reveals what kind of State we inhabit. Even though polygamy prosecutions are rare, they can involve hundreds of people, and, more importantly, engage thousands or even millions of Americans who avidly follow polygamy cases today, much as their predecessors did fifty years ago. The 2008 Texas raid on the Yearning for Zion ranch, for example, summarily separated over 400 children from their parents based on an anonymous phone call that turned out to be a hoax. ${ }^{279}$ Following and debating the case became a national pastime, facilitated no doubt by the popular TV show about polygamists, Big Love. ${ }^{280}$ Moreover, banning polygamy matters because the ban continues to play a role in immigration law.

Not coincidentally, that body of law plays a crucial role in defining boundaries between people who are deemed worthy of American citizenship, and those who are not. These immigration cases help answer the second question about whether the racial roots of polygamy doctrine continue to inform the application of today's ban. In substance and spirit, immigration law echoes nineteenth century discourse that framed polygamy as "barbaric," literally meaning "foreign." ${ }^{, 281}$ While racial discourse usually is more subtle than it was a century ago, immigration case law as recent as 1954 explicitly analogized polygamy to miscegenation. ${ }^{282}$

White supremacy has driven both polygamy doctrine and immigration restrictions from the outset. In 1874, Congress passed its second antipolygamy statute (the Poland Act), and the next year its first immigration restriction, the Page Act, which excluded Chinese contract laborers and prostitutes. ${ }^{283}$ While formally aimed at prostitution, it affected more Chinese polygamous wives. Immigration officials mistook many Chinese polygamous wives and concubines for prostitutes, out of ignorance

${ }^{279}$ See e.g., Sarah Corbett, Children of God, N.Y. Times MAG., July 27, 2008, at 1; David A. Farenthold, Case Against Sect May Not Be Over, WASH. Post, June 4, 2008, at A2; Emily Ramshaw, Texas Indicts 6 in Sect Inquiry, CHI. TriB., July 23, 2008, at 3; David Von Drehle, The Sins of the Fathers, Time, May 5, 2008, at 32.

\footnotetext{
${ }^{280}$ Big Love (HBO television broadcast 2006-present).

281 The NeW SHORTER OXFORD ENG. Dict. 181 (1993).

${ }^{282}$ In re B, 6 I. \& N. Dec. 305, 1954 WL 7870 (BIA).

${ }^{283}$ Kerry Abrams, Polygamy, Prostitution, and the Federalization of Immigration
} Law, 105 Colum. L. REv. 641, 643, 660 (2005). 
or disregard for Chinese families that included first wives (often left with the husband's family in China), second wives, and concubines. ${ }^{284}$ One Senator at the time condemned Chinese polygamy in language almost identical to anti-Mormon discourse. He claimed polygamy was "natural" for Asians and Blacks, ${ }^{285}$ in "us/them" language, describing "the Mongol race" as a "people to whom polygamy is as natural as monogamy is with us."286 Just as antipolygamists dubbed slavery and polygamy the "twin relics of barbarism,"287 proponents of Chinese exclusion used slavery to justify that policy. As Kerry Abrams explains, "[c]oolies and citizens were antithetical: A person willing to submit him or herself to a system of slavery could not adequately participate in a democracy.",288

The intertwined racial roots of immigration and polygamy still inform immigration law. Case law continues to ban polygamist wives from immigrating, even when the first marriage was ended through death or divorce. ${ }^{289}$ Just as the 1882 Edmunds Act barred jurors on the grounds of belief in polygamy, ${ }^{290}$ federal immigration law excluded "[a]liens who are polygamists or who practice polygamy or advocate the practice of polygamy" until $1990 .{ }^{291}$ Although the Immigration and Nationality Act of 1990 narrowed the ban, barring only "practicing polygamists" from entering the United States, ${ }^{292}$ a 2007 decision applied the old rule, excluding a woman from Yemen even though the death of the other wife meant that she was no longer a "practicing polygamist."293 The 2007 decision's citation of a 1962 case for the seemingly neutral proposition that "there is a strong

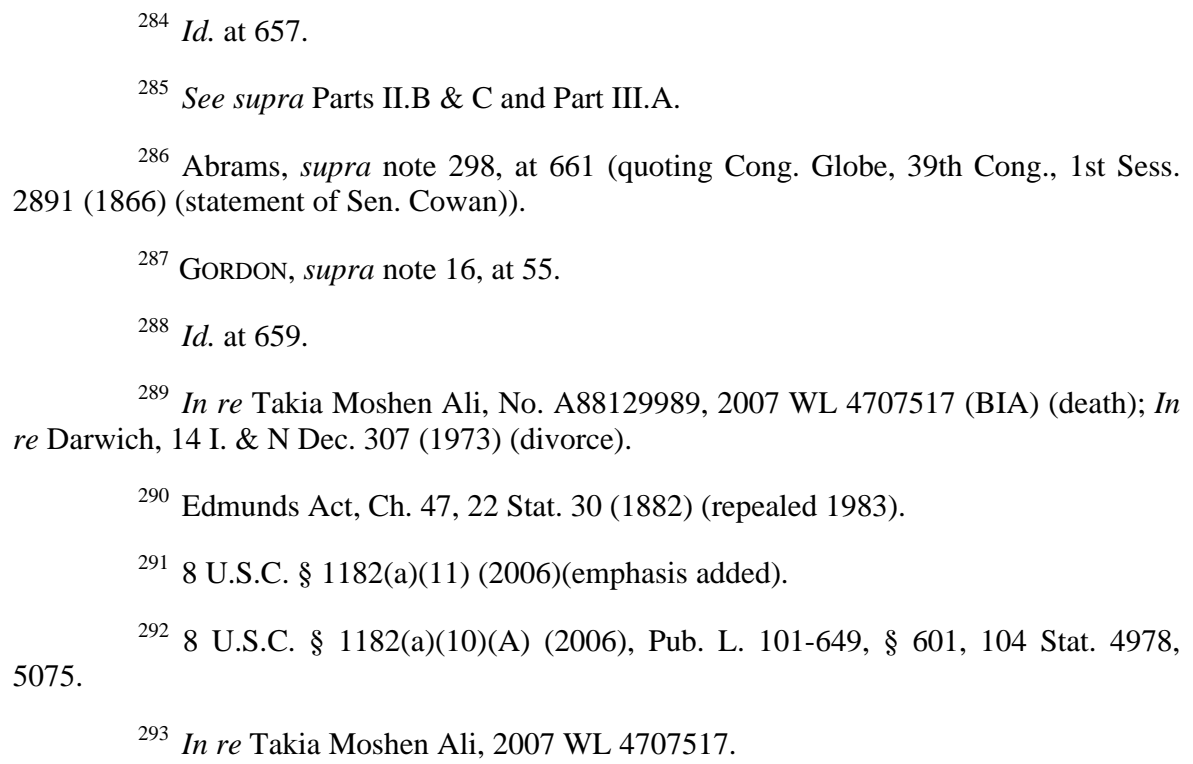


federal policy against polygamy in this United States," ${ }^{294}$ imports to this twenty-first century case the long-standing view of polygamy as foreign, barbaric, and un-Christian. The 1962 case explicitly articulated racial grounds for distinguishing "this United States" with non-Christian nations, withholding a polygamous wife's visa because "Anglo-American writers . . . emphatically" refuse to recognize a polygamous marriage, and further "such a marriage is not a marriage as understood among Christian nations." 295 Just eight years earlier, in 1954, the year of Brown v. Board of Education, and seventeen years before the Court would strike down bans on miscegenation, ${ }^{296}$ an immigration judge explicitly linked polygamy and miscegenation, reasoning that while these practices might be "legitimate" in "foreign jurisdictions," such instances of "moral turpitude" remained "contrary to the public policy of the United States." 297 The immigration ban, however, has more nuance than nineteenth century polygamy doctrine. Immigration case law recognizes some polygamous family relationships by sometimes treating children of one polygamous wife as stepchildren of another wife. ${ }^{298}$ In sum, immigration law has inherited a good measure of the nineteenth century reasoning that polygamy, though perhaps appropriate for "Asiatic and African" peoples, was inappropriate for a White America.

The third and final question, interrogating the link between the twin bans on polygamy and same-sex marriage, reveals a powerful and largely unnoticed connection between the two bans. DOMA's supporters raised status-based arguments to ban same-sex marriage that eerily echo nineteenth century concerns about polygamy fostering chaotic households and feral relationships that threaten civilization.

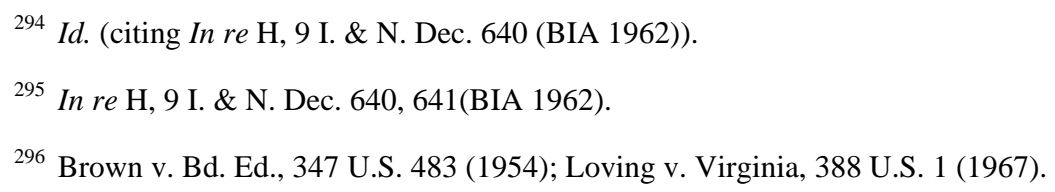

${ }^{297}$ In re B, 6 I. \& N. Dec. 305, 1954 WL 7870 (BIA). Another case refused immigration for a Jordanian citizen, asserting that the spouses "are Muslim citizens of Jordan. . . . [and Jordanian law] permits a man to have four wives," then citing Reynolds for the proposition that plural marriages "offend the public policy of the United States." See In re Darwish 14 I. \& N. Dec. 307, 308 (1973). Other aspects of immigration law also echo antipolygamy legislation aimed at the Mormons. Just as the cartoon "Defiance" portrayed Mormon polygamists as pirates, see supra text accompanying notes 261-263, immigrants are excluded as lacking "good moral character" if they are polygamists, prostitutes, or smugglers. See In re Applicant, 1998 WL 2018135 (INS) (citing Illegal Immigration Reform and Immigrant Responsibility Act of 1996, Pub. L. No. 104-208).

${ }^{298}$ In re Mohammed Alhazuddin, No. A99-431-760, 2006 WL 3712446 (BIA); In re Fong, 17 I. \& N. Dec. 212 (BIA 1980). 
That parallel appears most obviously in the very language of DOMA. DOMA explicitly incorporates the ban on polygamy by dictating that, for federal purposes, "the word "marriage" means only a legal union between one man and one woman as husband and wife." 299 Drafters could have said " $a$ man and $a$ woman," but used "one" instead. A fundamental canon of statutory construction dictates that legislatures say what they mean and do not use words unnecessarily. ${ }^{300}$ On its face, DOMA defends monogamy as well as heterosexuality.

Opponents of same-sex marriage reinforce DOMA's application to what might be called the "twin challenges" to monogamous, heterosexual marriage. Opponents cite antipolygamy precedent and tar same-sex relationships as feral, barbaric, and fundamentally uncivilized. In a recent case upholding DOMA, Andersen v. King County, ${ }^{301}$ Judge Johnson's concurring opinion for the Washington Supreme Court thoroughly develops the parallel between the polygamy ban and DOMA. First, Judge Johnson linked government and marital forms by quoting the 1885 polygamy case Murphy v. Ramsey: ${ }^{302}$

$[\mathrm{N}] \mathrm{o}$ legislation can be supposed more wholesome and necessary in the founding of a free, self-governing commonwealth . . . than that which seeks to establish it on the basis of the idea of the family, as consisting in and springing from the union for life of one man and one woman. ${ }^{303}$

Situating monogamous marriage as central to Western democracy frames alternatives like same-sex marriage as uncivilized, even barbaric. This claim runs throughout DOMA's legislative history, often appearing via quotes of the same language from Murphy $v$. Ramsey.

2991 U.S.C. $\S 7$ (2000) (emphasis added). A recent immigration case recognized DOMA's ban on polygamy. See In re Jose Mauricio Lovo-Lara, 23 I \& N Dec. 746, 2005 WL 1181062 (BIA) (allowing immigration of a male-to-female transsexual's male spouse due to their home jurisdiction recognizing the sex change).

300 “ $[\mathrm{I}] \mathrm{n}$ interpreting a statute a court should always turn to one cardinal canon before all others. .. . [C]ourts must presume that a legislature says in a statute what it means and means in a statute what it says there.” Connecticut Nat'l Bank v. Germain, 503 U.S. 249, 252 (1992).

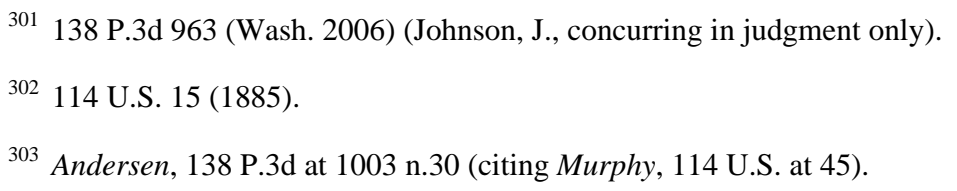


A House Report on DOMA also quoted the full "free, selfgoverning commonwealth" quote from Murphy, ${ }^{304}$ as did Senator Coats' defense of DOMA. ${ }^{305}$ Elaborating on the Murphy quote, Coats claimed that monogamous, heterosexual marriage "civilizes our society by humanizing our lives," implicating alternatives like polygamous and gay unions as outside civilization and even less than fully human:

Marriage is the institution in our society that civilizes our society by humanizing our lives. It is the social, legal and spiritual relationship that prepares the next generation for duties and opportunities. $^{306}$

Coats' reference to gay people being unfit to raise the next generation echoes the antipolygamist cartoons depicting chaotic polygamous households and racial degeneration through multiracial children. He made no apology for embracing a nineteenth-century view of marriage, asserting, after quoting Murphy, "I don't think anything has changed that would change that definition given by the Supreme Court more than a hundred years ago." 307

Indeed, Coats embraced a status-based view that Elizabeth Cady Stanton and others condemned as outdated in $1860 .{ }^{308}$ He claimed divine authority for his views, just as the Supreme Court of his state, Indiana, did a century earlier to uphold miscegenation bans in Gibson. ${ }^{309}$ Coats asserted:

The definition of marriage is not created by politicians and judges, and it cannot be changed by them. It is rooted . . . in our nature as human beings. It is the union of one man and one woman. This fact can be respected, or it can be resented, but it cannot be altered. ${ }^{310}$

${ }^{304}$ H.R. Rep. No. 104-664, at 40 (1996), reprinted in 1996 U.S.C.C.A.N. 2905, 2916 (quoting Murphy, 114 U.S. at 45).

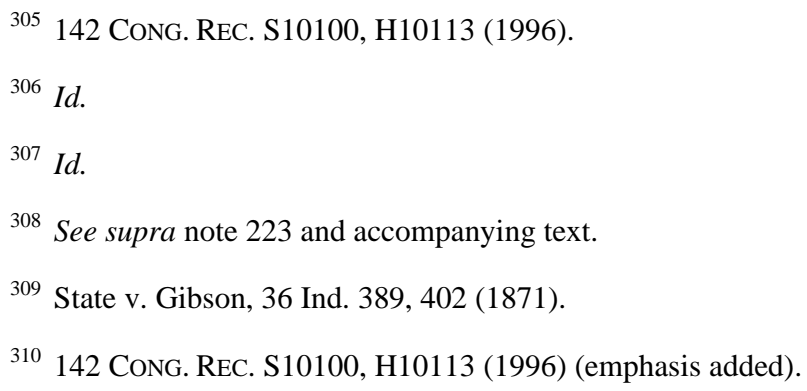


Coats was hardly alone in grounding DOMA on status-based views of marriage that had not, and indeed could not, change.

Representative Charles Canady, as Chairman of the Judiciary Committee's Subcommittee on the Constitution, opened the House Judiciary hearings on DOMA by declaring: "[T]he traditional family structure-centered on a lawful union between one man and one womancomports with nature and with our Judeo-Christian moral tradition. It is one of the essential foundations on which our civilization is based." 311 "Barbaric" literally means "foreign" and "barbarism” denotes behaving or speaking like a foreigner. ${ }^{312}$ In this view, "civilization," is a term that carries highly racialized freight. Once self-styled "defenders" of heterosexual marriage claim exclusive access to civilization, race and ethnicity quickly come to the fore. Anti-gay marriage crusader Maggie Gallagher echoed this theme when she worried that industrialized nations are not reproducing enough to replace existing populations, making those societies vulnerable to take-over by outsiders. ${ }^{313}$ Recall the cartoon images reproduced above that depicted Turks, Irish, Scottish, Japanese, and Chinese figures as embodying the threat that Mormon polygamy posed to civilization by jeopardizing white supremacy. ${ }^{314}$ Recall too Francis Lieber and the Supreme Court's use of the first-person pronouns- "I" and "our"to contrast with "Asiatic and African peoples," 315 to designate them as "them" and "Other" in their barbaric, foreign backwardness. In short, nineteenth century antipolygamists and twenty-first century opponents of same-sex marriage took their language and arguments from the same page from the Status-is-Determinative playbook.

Amherst Professor Hadley Arkes, speaking for the academy in the DOMA deliberations, also sounded as if he were speaking a century ago. He shared a teleological approach with Lieber and Barthelow, who vilified

${ }^{311}$ Full Committee Markup—the Defense of Marriage Act: Hearing on H.R. 3396 Before the H. Comm. on the Judiciary, 104th Cong. (1996) (statement of Del. Charles T. Canady, Chairman, H. Comm. on the Judiciary), 1996 WL 324376 (Westlaw) (emphasis added).

312 See supra note 296, at 181.

313 Declaration in Support of Plaintiff Campaign for California Families’ Motion for Summary Judgment, Randy Thomasson v. Gavin Newsom, [case citation as reported] (Cal. 2004) (No. CGC-04-428794).

${ }^{314}$ See supra Part II.B-C.

${ }^{315}$ Lieber, supra note 191, at 233-34; Reynolds v. United States, 98 U.S. 145, 164, 165-66 (1879). 
Mormon polygamy for violating the natural law by forming primitive marriages fit only for primitive races. ${ }^{316}$ Arkes, for his part, asserted a natural teleology of human intimacy that echoed nineteenth century assertions about a natural progression of civilization away from the primitive East and toward the civilized West, as natural and unalterable as the sun's progress through the sky. Arkes testified to the "natural teleology of the body" ${ }^{317}$ that makes heterosexuals inherently superiority to gay people. Like his predecessors, he pilloried his target by comparing them to another unpopular group:

If the law permitted the marriage of people of the same sex, what is the ground of principle then on which the law would rule out as illegitimate the people who profess that their own love is not confined to a coupling of two, but connected in a larger cluster of three or four? .. . [W] e would be back, in principle, to the acceptance of polygamy. And while we are at it, we might ask how the law, on these new premises, rules out marriage between parents and their grown children. ${ }^{318}$

Arkes' explicitly recognized the status-based foundation for his argument, naming it "nature," and charged same sex marriage supporters with advocating a contract model of marriage. In doing so he claimed a fixed status for men and women (and therefore gays and heterosexuals), contrasting natural law to human-made positive law:

[G]ay activists ... have the most profound interest, rooted in the logic of their doctrine, in discrediting the notion that marriage finds its defining ground in "nature" .... In this construction, marriage does become a matter solely of convention and opinion, and therefore it can be given virtually any shape by the positive law. ${ }^{319}$

\footnotetext{
${ }^{316}$ See supra notes 117-120, 191-193 and accompanying text.

317 Testimony On the Defense of Marriage Act: Hearing on H.R. 3396 Before the
} H. Comm. on the Judiciary, 104th Cong. (1996) (statement of Hadley Arkes, Professor, Amherst College), 1996 WL 256693 at *11.
${ }^{318}$ Id.
${ }^{319} I d$. 
In this light, the anti-gay "defense" of marriage is revealed, at its core, to defend status over contract, just like antipolygamy discourse of a century earlier.

Rather than allow adults to "contract" for the type of marriage that suits them, inheritors to the racial arguments against plural marriage proceed from a similar status-based premise that heterosexual marriage is dictated by nature, biology, or God (and thus not subject to human alteration). This "natural teleology of the body," 320 in Arkes phrasing, therefore, must mean that husbands and wives perform standard and complementary roles. In this system, the "one man and one woman" language mandates that one spouse will be the man, and the other will be the woman.

Arkes is no outlier. New York upheld the ban on same-sex marriage on these grounds, invoking status by calling it "intuition and experience," instead of nature or God. ${ }^{321}$ Without specifying the genesis or nature of the intuition or experience, the court reasoned "that a child benefits from having before his or her eyes, every day, living models of what both a man and a woman are like.”322 Similarly, philosopher John Finnis grounded his opposition to same-sex marriage on a premise of fixed, biological complementarity between men and women:

The union of the reproductive organs of husband and wife really unites them biologically ... in respect of that function, the spouses are indeed one reality .... But the common good of friends who are not and cannot be married (for example, man and man, man and boy, woman and woman) has nothing to do with their having children by each other, and their reproductive organs cannot make them a biological (and therefore personal) unit. ${ }^{323}$

\footnotetext{
${ }^{320}$ Id.

${ }^{321}$ Hernandez v. Robles, 855 N.E.2d 1, 7 (N.Y. 2006)

${ }^{322}$ Id. at 7-8. While studies generally indicate that children raised by same-sex
} couples fare as well as those raised by heterosexual parents, there are some differences in how closely the children conform to traditional gender scripts. Judith Stacey \& Timothy J. Biblarz, (How) Does the Sexual Orientation of Parents Matter?, 66 Am. Soc. Rev. 159, 168, 171 (2001). Daughters in these families, for example, are a little more likely than their counterparts to dream of being doctors rather than nurses. Id. Sons, similarly, are a little more chaste. $I d$.

323 John M. Finnis, Law, Morality, and “Sexual Orientation,” 69 Notre Dame L. REV. 1049, 1066 (1994). 
These arguments from status carry important consequences.

Coverture was grounded in ideas about the status of women as inherently inferior and needing their husbands' control and protection, justifying the status of the married couple as one legal person, whose interests were represented by the husband. Finnis, Arkes, Coates, and the highest courts of New York and Washington, share a status-based view of both gender and marriage that, logically extended, could lead to reinstating coverture, banning women from engaging in wage labor, voting, or keeping their maiden names. Assuming that we do not want, as a country, to move backward to nineteenth century understandings of gender, race, and marriage, and further assuming that we retain the twin bans on same-sex marriage and polygamy, we must update the rationale for both.

This Article stops short of articulating that new rationale. Instead, relying on Henry Maine, it suggests that contract, generally, can improve on the status-based reasoning that brought us miscegenation laws, The Mormon Coon, and DOMA. A contractual view of marriage would allow adults to consent to different types of marriage.

This approach rides the horse in the direction it seems to be headed. The larger culture may well be puzzling out the benefits and dangers of status and contract in lively discussions about polygamous Mormons while watching Big Love or reading news about the raid on the Yearning for Zion ranch. It is hard to imagine why else polygamists would once again attract national attention, since the eccentric religious sects remain technologically, geographically, and socially isolated in remote western compounds. Perhaps polygamists represent, in the public imagination, extremes of both status and contractualization in families. Families, the core of status for Henry Maine, can now be contractualized more than ever through doctrines governing reproductive technologies, no-fault divorce, and marital contracting. ${ }^{324}$ As this Article details, status won in the nineteenth century

${ }^{324}$ See generally DeBOra L. Spar, The Baby Business (2006); AMERICAN LAW Institute, Principles of THE LAW OF FAmily Dissolution $\S 7.03$ (2002). Economic conditions of late industrial capitalism have also contributed to producing what sociologist Judith Stacey calls "postmodern families," which, in line with contractual pluralism, take various forms such as blended families, open adoptions, and same-sex couples. JUDITH Stacey, In the Name of the Family: Rethinking Family Values in the Postmodern AGE 10 (1996). The very terminology of discussing "families" rather than "the family," signals a shift from status to contract, from stasis to pluralism. Id. For a critique of pluralist understandings of family, see DAVID BlANKENHORN, THE FUTURE OF MARRIAGE (2007) and Mary AnN Glendon, The TRANSFORMATION OF FAMily LaW: STATE, LAW, AND FAMILY IN the United States and Western Europe (1989); The Family, Civil Society, and the STATE (Christopher Wolfe ed., 1998). For a critique of contractualization in other spheres,

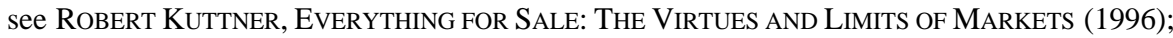
Michael Sandel, What Money Can't Buy: The Moral Limits of Markets, in RethinKing 
assault on Mormon polygamists. But the outcome of this round remains to be seen, where arguments once again pit status against contractually-based expansions of marriage. ${ }^{325}$

This Article concludes on a cautionary note, noting the imperfect match when nineteenth century polygamy disputes are mapped onto today's same-sex marriage debate. Just as contract and status played complex roles in polygamy and monogamy a century ago, today's debates on same-sex marriage and polygamy elude reductionist description in status and contract terms. On its face, both the federal antipolygamy statutes and modern DOMAs define marriage as one man and one woman. ${ }^{326}$ Yet they differ in the level of punishment for those who depart from the rule, reflecting a gradual move toward contractualization even in DOMA's status regime. The federal DOMA defines marriage as one man and one woman and allows a state opposing same-sex marriage to refuse to recognize a samesex marriage performed in a sister state, a much milder provision than the federal antipolygamy statutes that criminalized bigamy and stripped polygamists of citizenship through measures like disenfranchisement. ${ }^{327}$ Returning to Henry Maine’s framework, we might see this difference

Commodification: CAses And ReAdings in LAW ANd Culture 122 (Martha M. Ertman \& Joan C. Williams eds., 2005).

${ }^{325}$ Like many grand battles between purported opposites, the conflict between status and contract resists simplification, especially in the family law context. Although Henry Maine pitted family as the organizing principle of a status-based society against the individual who occupies the center of gravity in a contractual regime, family itself has long been a hybrid of status and contract. Carole Pateman, The SeXual Contract 2 (1988). Prior to Enlightenment individualism, contractualism in marriage took the form of private agreements, independent of state or church sanction or registration. WITTE, supra note 228, at 10-12. Examples of continuing status-based regulations of marriage include incest prohibitions on who can marry, although the precise definition of what constitutes an incestuous union changed over time. Courtney Megan Cahill, Same-Sex Marriage, Slippery Slope Rhetoric, and the Politics of Disgust: A Critical Perspective on Contemporary Family Discourse and the Incest Taboo, 99 Nw. U.L. REV. 1543 (2005). You might say that family is like a sandwich, with status as the bread and contract as the filling. Just as sandwiches require both bread and filling, family requires both status and contract (otherwise it is a salad or bread alone). But the family sandwich has evolved over the last century and a half, from something like a plain bologna sandwich (mostly status/bread, with a single thin slice of contract/filling) to something more like a burrito (thin tortilla enveloping a fat jumble of fillings).

${ }^{326}$ See, e.g., Defense of Marriage Act, Pub. L. No. 109-199, § 3, 110 Stat. 2419, 2419 (1996) (codified at 1 U.S.C. § 7) (“[T]he word 'marriage' means only a legal union between one man and one woman as husband and wife.”).

${ }^{327}$ Pub. L. No. 109-199, § 2(a), 110 Stat. at 2419 (codified at 28 U.S.C. § 2738C). 
between the polygamy and DOMA legislation as a move toward contractualism by increasingly tolerating people's different choices in family formation, even if remnants of status remain in the federal definition of marriage. ${ }^{328}$

\section{CONCLUSION}

Polygamy has a complex history, linked to America's history of invidious hierarchies based on race and sex. Reynolds v. United States and other cases upholding the criminalization of Mormon polygamy in the nineteenth century reasoned that polygamy could be banned due to its association with “African and Asian peoples” and "stationary despotism.”,329 Judicial, medical and political discourse as well as cartoons of the day show that most Americans worried at least as much about Mormon treason in establishing a separatist theocracy as about plural marriage per se. Moreover, mainstream opposition to Mormon control of Utah stemmed from a widespread view that polygamy, while "natural," among the "inferior colored races," was so "unnatural”330 for Whites that the progeny of Mormons constituted a new species that resembled those supposedly backward races, degenerating the White race and undermining white supremacy. African American commentators, unsurprisingly, did not articulate race degeneration arguments, opting instead to oppose polygamy as akin to slavery, both defended with Biblical and states' rights arguments. Feminists, for their part, waffled about Utah granting women the vote and whether to deploy polygamy's mistreatment of women to reveal monogamy's abuses, but ultimately came to oppose polygamy. Even if marginalized groups had different reasons for opposing polygamy, the legal, political, and medical elites who shaped the legal doctrines grounded their decision on racial status. Consequently, we should read American antipolygamy law in light of their intent to remedy political and race treason.

Two theoretical frameworks help decode the racial underpinnings of American polygamy law. The concept of Orientalism helps explain the political and cultural impact of depicting overwhelmingly White Mormons

328 Those remnants remain important, however, since federal recognition of marriage matters much more in the early twenty-first century than it did a century ago, before the advent of Social Security and other federal benefits that now accompany marriage.

${ }^{329}$ Reynolds v. United States, 98 U.S. 145, 164, 165-66 (1879)

330 See Hereditary Descent, supra note 113, at 213. 
as Asians and Black in cartoons, setting up a discourse in which a subject people inevitably suffer subjugation. Moreover, Henry Maine’s 1864 assertion that progressive societies move "from status to contract" ${ }^{331}$ invites us to view the cartoons as visceral defenses of status in the face of encroaching contractualism in the late nineteenth century. Still, status and contract offer only partial clarity. Both sides of the polygamy debates asserted both contractual and status-oriented arguments. When antipolygamists deprived White Mormons of citizenship rights like voting to punish their race treason, it simultaneously furthered and undermined white supremacy. By revealing Whiteness as an insider status that was so clubby as to exclude even some White people (like Mormons, Irish, and Italians), ${ }^{332}$ racist antipolygamists unwittingly provided the tools to dismantle the very system they sought to protect. If Whites are made instead of born, purportedly natural categories are mere cultural constructs. Deprived its status-based foundation, the claim that Whites naturally practice monogamy, while "Asiatic and African peoples" are naturally polygamous, is literal nonsense.

If status cannot justify antipolygamy law, we must search for an alternative justification, should we decide to retain the doctrine. Besides cleaning out this doctrinal closet of century-old dust bunnies, this process could well clarify our thinking about marriage more generally and point the way toward resolving the same-sex marriage debate.

\footnotetext{
${ }^{331}$ MAINE, supra note 13.

332 Bentley, supra note 92.
} 